\title{
A promoção e a produção das redes de águas e esgotos na cidade de São Paulo, $1875-1892$
}

\author{
Cristina de Campos \\ Programa de pós-graduação da Faculdade \\ de Arquitetura e Urbanismo da Universidade \\ de São Paulo
}

RESUMO: Este artigo tem como objetivo analisar como surgiram as redes de águas e esgotos em São Paulo nas últimas décadas do século XIX. Para a construção do novo sistema de abastecimento da cidade, o governo provincial contratou uma empresa privada, a Companhia Cantareira \& Esgotos, responsável pela execução e administração desse sistema. Como não conseguiu cumprir o acordo firmado com o governo, a companhia perde a concessão dos serviços e é encampada pelo Estado, passando a denominar-se Repartição Técnica de Águas e Esgotos. Dessa forma, constatamos que o Estado passa de promotor a produtor dessas redes em São Paulo.

PALAVRAS-CHAVE: Infra-estrutura urbana. Urbanização. Saneamento. Companhia Cantareira. São Paulo.

ABSTRACT: This article seeks to analyse the creation of the water and sewerage systems in the city of São Paulo in the last decade of the $19^{\text {th }}$ Century. The provincial government contracted a private company, the Companhia Cantareira \& Esgotos, for the construction of the new water supply system, its execution and administration. Unable to fulfil its part in the contract, the company loses the rights to the services, and is taken over by the State, becoming the "Water and Sewerage Technical Department [Repartição Técnica de Águas e Esgotos]". Therefore, the State moves from the promotion to the production of this infrastructure in São Paulo.

KEYWORDS: Infrastructure. Urbanization. Sanitation. Cantareira Company. São Paulo. 
1. RODRIGUES; VALLE, 1903

2.As atividades do saneamento não englobavam apenas as redes de águas e esgotos. Envolviam outras tarefas nesse final de século XIX: dessecação/drenagem de pântanos e alagadiços, retificação de leitos de rios, dentre outros.Aqui enfocaremos apenas as redes de águas e esgotos de São Paulo

3.A vinda de estrangeiros para substituir o braço escravo nas lavouras de café era um debate presente no governo imperial também entre os próprios cafeicultores. Entre 1865 e 1866 corria um projeto de imigração de norte-americanos para São Paulo no Ministério da Agricultura e em anos anteriores ocorreram as experiências com imigrantes europeus na Fazenda Ibicaba do senador Vergueiro.
É aqui neste terreno que a medicina encontra as fronteiras da engenharia.

Rodrigues e Valle

Neste artigo exploramos como foi a criação das redes de águas e esgotos na cidade de São Paulo, por meio das várias propostas recebidas nas últimas décadas do século XIX, momento em que a cidade começa a sentir os efeitos do crescimento econômico e populacional gerado pela atividade agroexportadora. É também esse final de século que marca o início da criação do assim chamado complexo cafeeiro (BEIGUELMAN, 1977; CANO, 1977), que investiu grandes massas de capital em atividades paralelas e ou complementares à economia cafeeira, criando dessa forma as condições favoráveis para o desenvolvimento da industrialização nas primeiras décadas do século XX (SINGER, 1974). A prioridade dada ao saneamento² tinha objetivos bem definidos para o complexo cafeeiro: 1) permitir que cidades importantes para a economia do café como Santos, São Paulo e Campinas fossem saneadas, fomentando o seu crescimento; 2) a fixação e a reprodução da força de trabalho estrangeira $^{3}$ para as lavouras, importante para a própria manutenção dessa economia de exportação; 3) o desenvolvimento de cidades e a aceleração do processo de urbanização, bem como a criação dos mercados de trabalho urbano e de consumo (SINGER, 1974). Entre essas variadas atividades, este artigo focalizará a construção de todo um aparato de saneamento, as redes de águas e esgotos, necessário ao crescimento populacional e ao próprio desenvolvimento urbano e territorial da cidade e do Estado. Indagamos quando o abastecimento d'água para a cidade passou a ser uma das questões prioritárias e presente dentro do debate político do período. Assim, acompanhamos quais foram as propostas apresentadas ao governo provincial iluminando a escolha da Companhia Cantareira para executar tal obra de infra-estrutura.

Os dois marcos temporais contemplados aqui são, primeiro, o surgimento da empresa privada Cantareira \& Esgotos (1 877) e, posteriormente, a encampação dessa companhia pelo Estado, em 1892, e a conseqüente criação da Repartição de Águas e Esgotos (RAE) da capital (1893). Analisando essas duas organizações, observa-se que elas surgiram em momentos diferenciados. A Cantareira \& Esgotos foi criada para atender uma demanda do Estado, e a RAE foi organizada para tomar para si a responsabilidade da construção e do gerenciamento das referidas redes. Com essa constatação, nota-se que, em um primeiro momento, o Estado Imperial promovia essa atividade de saneamento, mas não a produzia, pelo contrário, chamava investidores privados interessados em implantar e administrar tais serviços, como foi o caso da Cantareira \& Esgotos. Em um segundo momento, o Estado Republicano, com a encampação da companhia particular, toma a responsabilidade de produção e administração das redes de águas e esgotos, passando assim à condição de produtor. A essa nova postura deve-se muito à mudança do regime político, de Monarquia para República, que o país atravessou na penúltima década do 
século XIX. Durante o regime monárquico, existia certa dificuldade do aparelho de Estado gerenciar serviços, não sendo permitido aos governos provinciais assumirem diretamente tais responsabilidades, política essa que emperrava o andamento de determinados setores públicos dentro das Províncias. Com o advento da República (1889) e a descentralização política por ela executada, os Estados da federação tinham autonomia para criar e gerenciar órgãos, secretarias e outras instituições públicas voltando-as para os problemas mais urgentes da cidade e do Estado. Nesse sentido, entendemos a criação da própria RAE, do Serviço Sanitário, das Comissões Sanitária e de Saneamento como um meio de gerenciar os problemas que vinham se arrastando desde a época do Império.

Desenvolvimento econômico e a promoção da infra-estrutura em São Paulo

A atividade de infra-estrutura, ramo em que se insere o saneamento, é precedida por um surto de desenvolvimento econômico. Por volta de 1860, a cidade de São Paulo pouco impacto causava dentro da economia imperial, gerando assim pouca movimentação financeira, sendo os investimentos em infraestrutura parciais. Na época da Colônia, a economia baseava-se na agricultura (abastecimento e exportação), nos tropeiros que transportavam mercadorias e no comércio de escravos.

As duas formas de economia agrícola dominavam o cenário brasileiro, sendo que a de abastecimento espraiou-se por regiões não ocupadas pelas plantations, chegando a dispor de áreas muito maiores de cultivo, como foi o caso do hinterland da cidade de São Paulo. O comércio de alimentos, praticado por muito tempo por meio do escambo e depois envolvendo pequenas trocas monetárias, rendia pouco, porém, foi esse extrato insignificante que manteve São Paulo, estendeu-se pelo interior e criou uma extensa rede comercial, contribuindo ainda para sua elevação dentro do patamar econômico da Colônia. Logo São Paulo seria elevada à categoria de sede da Capitania de São Vicente, depois à condição de cidade, em 1711 . A criação dessa rede comercial é que viabilizaria, segundo Singer (1974), o desenvolvimento de São Paulo.

Entre os séculos XVIII e XIX, a economia paulista começou a se abrir com o açúcar para a agricultura de exportação, sem deixar a de abastecimento. O escoamento da produção do açúcar acontecia de forma rudimentar pelo porto santista, em uma operação que acabou por integrar as cidades de Santos e São Paulo ${ }^{4}$. $O$ sucesso da produção cafeicultura paulista trouxe para São Paulo outros benefícios, pois começou a atrair os produtores que fixaram residência na cidade, impulsionando assim o comércio local e ampliando o crescimento do setor de serviços da economia urbana. Mesmo sendo um modesto núcleo urbano com dificuldades em demarcar sua área urbana e rural lque ainda produzia a subsistência local), em 1860 São Paulo passou por uma série de melhoramentos urbanos. Esse destaque para a cidade deveu-se não somente à economia de exportação, mas também à importância política que São Paulo

Annals of Museu Paulista. v. 13. n.2. Jul.- Dec. 2005.
4. A integração de São Paulo com outras cidades, compondo assim um "eixo" de produção, comercialização/mercado e escoamento, intensificou-se, sobretudo, no final do século XIX e início do XX com o cultivo do café. Sobre essa rede de cidades paulistas ver CAMPOS (2002). 
5. Os melhoramentos urbanos não ficaram restritos apenas a São Paulo, eles se estenderam por muitas cidades do interior como Campinas, São Carlos e Araraquara, principalmente depois dos surtos epidêmicos de febre amarela nas últimas décadas do século XIX. Ainda destacamos que o próprio Estado destinou parte de seus orçamentos para essas reformas (CAMPOS, 2002) vinha conquistando desde que se tornou capital da Província em 1822 e passou a abrigar a Faculdade de Direito, em 1828 (SINGER, 1974).

O café, à medida que conquistava cada vez mais espaço nas mesas estrangeiras, aumentando assim sua demanda no mercado internacional, ganhava novas áreas de cultivo entre São Paulo e Rio de Janeiro. Expandiu-se com maior força dentro do hinterland paulista, começando a gerar impactos no desenvolvimento econômico da cidade, iá que as transações comerciais e tributárias passaram a ocorrer nas praças de São Paulo e Santos. A partir das últimas décadas do século XIX, a cidade de São Paulo começou a sentir de forma direta e indireta, segundo Singer, os resultados da expansão cafeeira, geradores de parte das condições que permitiram o surto industrial e seu conseqüente crescimento explosivo. Os efeitos diretos foram o aumento demográfico $152 \%$ entre 1872 e 1886) e a aceleração do processo de urbanização, fazendo com que a cidade dobrasse sua área de ocupação. Os efeitos destacados por Singer (1974) são:

1) A ampliação da função de entreposto comercial com a comercialização do café, que passara a ser transportado pela ferrovia, com mais segurança, rapidez e economia, otimizando os lucros.

2) $\bigcirc$ surgimento de novos povoamentos, bem como o crescimento de cidades existentes na zona produtora, graças à chegada da ferrovia e dos lucros advindos do café, que contribuíram para a urbanização do Estado, com núcleos urbanos de destaque como Campinas e Ribeirão Preto.

3) Mesmo com a comercialização do café sendo realizada em Santos, deu-se em São Paulo a localização dos estabelecimentos bancários, e o surgimento de um mercado de capitais.

4) A vinda de cafeicultores para a capital, além de ampliar o papel comercial da cidade acima descrito, contribuiu ainda para o seu crescimento demográfico e urbano.

5) A permanência de imigrantes em São Paulo favoreceu o aumento populacional e a intensificação da oferta de mão-de-obra especializada. A imigração e a própria migração interna propiciaram a formação de um mercado de trabalho urbano.

6) A constituição de uma extensa malha ferroviária, produzida com capitais estrangeiros e nacionais, rasgou o território paulista, ligando-o a outras regiões.

7) A criação de um aparato de infra-estrutura urbana ${ }^{5}$ para que a cidade pudesse comportar todo esse crescimento e continuasse a se desenvolver.

Será a partir desse surto de desenvolvimento impulsionado não apenas pelo café que as obras de infra-estrutura tornar-se-ão imprescindíveis para a 
cidade. Podemos dizer que a implantação da rede de infra-estrutura em São Paulo foi promovida com os recursos arrecadados pelo Estado, sobretudo pelo comércio e exportação do café, mas também do algodão, do açúcar e de outros produtos agrícolas aqui produzidos.

\section{O complexo cafeeiro e a infra-estrutura na cidade de São Paulo}

Década de 1860. A cidade de São Paulo, antes entorpecida pelo marasmo da vida de um pequeno vilarejo, começou a crescer e a atrair a atenção do país. Com a chegada da ferrovia, inaugurada pelos ingleses em 1867 para transportar o café produzido pela Província, pode-se dizer que a modernidade batia à porta de São Paulo. Logo se instalaram na capital fazendeiros, casas bancárias e novos estabelecimentos comerciais, para um público consumidor cuja tendência de crescimento era alta. Sendo esse o cenário de desenvolvimento da cidade, companhias particulares e o governo provincial rapidamente passaram a promover uma série de melhorias na infra-estrutura básica da cidade para comportar os novos habitantes, bancos e comércio, e criar equipamentos capazes de garantir a continuidade do crescimento e do desenvolvimento da Paulicéia.

Os primeiros melhoramentos urbanos realizados na cidade ocorreram por volta de 1860. Segundo Singer (1974), podemos citar: construção de um novo matadouro e de uma nova penitenciária (1852); melhorias no sistema de abastecimento de água a partir de 1851 e pavimentação das principais ruas da cidade, concluída em 1860. Essas mudanças continuaram nas décadas seguintes, mostrando como a cidade vinha progredindo a passos rápidos: iluminação pública com lâmpadas a gás (1872); inauguração do serviço telefônico (1 884); organização da Cia. Cantareira de Águas e Esgotos (1877), início do serviço de bondes (1872) e outras obras de melhoramentos em ruas e calçadas. Todas essas melhorias são reflexo direto do desenvolvimento da cafeicultura e de outros produtos agrícolas em São Paulo ${ }^{6}$. Segundo autores como Cano (1977) e Costa (2003), esses melhoramentos faziam parte do assim chamado complexo cafeeiro, que consistia na criação de uma série de atividades econômicas com a finalidade de oferecer suporte ao crescimento e expansão da lavoura cafeeira. Aliás, como ressalta Costa (2003, p. 55), "não foi o café em si, mas a estrutura social organizadora dessa atividade agrária que possibilitou seu amplo êxito", permitindo a construção desse complexo. A cidade de São Paulo também fazia parte do referido complexo, já que abrigava fazendeiros e outras instituições vinculadas diretamente à lavoura cafeeira. A noção de complexo cafeeiro está ligada ao desenvolvimento de relações capitalistas de produção, com a introdução do trabalho assalariado e o fim da escravidão ${ }^{7}$ (CANO, 1977).

Estabelecido o complexo, esse serviu como suporte ao café, também contribuindo à urbanização e à própria constituição de uma estrutura urbana diferenciada, visível não apenas na cidade de São Paulo, mas também em outras
6. O café trouxe para a praça de movimentação financeira paulista um grande volume de capitais, mas seria injusto atribuir apenas à cafeicultura esse boom de desenvolvimento. Outras culturas contribuíram, em parcela menor, para esse crescimento da economia.

7.Cano (1977) diferencia o Vale do Paraíba e o Oeste Paulista por representarem cada um formas dinâmicas diferenciadas No Vale do Paraíba existia o complexo escravista, baseado fortemente em atividades ligadas ao tráfico negreiro e no trabalho escravo. No Oeste Paulista operava uma outra vertente que, apesar de ter iniciado com o trabalho escravo, possuía uma dinâmica de acumulação capitalista. Singer (1974) também sinaliza outra importante diferenciação: no regime escravista existe a economia de subsistência e com o trabalho livre há a economia de mercado. 
cidades do interior paulista, em finais do século XIX. Esclarecidas as motivações da instituição do complexo, partimos agora para a compreensão de como se deu a produção dessa infra-estrutura e, em especial, das obras de abastecimento d'água e rede de esgotos que contaram com a participação do Estado e de capitais estrangeiros e nacionais.

Estado promotor do saneamento: as redes de abastecimento para a cidade de São Paulo

Na segunda metade do século XIX, o saneamento fazia-se necessário, primeiramente, pelo aumento demasiado de sua população urbana, que precisava da água para consumo próprio e também para transportar seus dejetos. À medida que a cidade crescia, os antigos métodos para consumo de água ou despejo dos dejetos, feitos pelos escravos domésticos, tornavam-se ineficientes e condenados pelas primeiras teorias médicas sobre transmissão das doenças. Além desses fatores, esses métodos traziam consigo o cenário de uma cidade atrasada, imagem essa que não refletia os anseios da burguesia cafeeira em ascensão (REIS FILHO, 2002).

A produção do saneamento na cidade de São Paulo fez-se junto ao desenvolvimento das relações capitalistas, pois constitui o saneamento "um valor de uso complexo" para questões ligadas à saúde, à reprodução da força de trabalho e à própria reprodução do capital (BUENO, 1994, p. 17). Segundo a autora, o saneamento possibilitaria também a mercantilização "de inúmeras atividades anteriormente restritas ao universo da moradia - bares, restaurantes, lavanderias, etc. - promovendo uma potencialização geral da acumulação no meio urbano". Ou, em outras palavras, existia "mercado" para o consumo da água e uso das redes de esgotos na cidade. Mesmo com a presença de consumidores, o problema que se colocava era quanto à produção das redes por causa de seu alto custo, o que a tornava inviável ao capital individual pelo seu longo período de rotação, fazendo com que o investidor demorasse para obter lucro. Além disso, tal investimento apresentava elevado grau de risco, havendo ainda a existência de barreiras políticas e judiciais (BUENO, 1994, p.20). A cidade de São Paulo oferecia oportunidades de serviços em vários setores, como o de transportes, mas, assim como o saneamento, exigia pesadas somas de capitais, inviabilizando a empresa para um único investidor. A saída adotada foi a união de vários capitalistas que contribuíam com um determinado valor para formar grandes companhias. Dessa forma, as companhias possuíam muitos acionistas, nacionais e estrangeiros, pessoas influentes na política e na economia do país, que diversificavam os seus capitais em diferentes atividades comerciais, bancárias e de serviços, como as ferrovias, transportes urbanos, navegação fluvial e marítima, casas comerciais, etc. (BRITO, 2000).

Conforme foi explicado na introdução deste artigo, durante as últimas décadas do Império, o governo paulista incumbia-se mais na promoção da infra- 
estrutura, concedendo licenças e privilégios a companhias e grupos privados interessados em estabelecer e explorar esses serviços no território brasileiro. Geralmente representado pela figura do engenheiro fiscal, cabia ao governo a tarefa de fiscalizar se esses serviços estavam sendo prestados com regularidade e dentro dos parâmetros regidos pelo contrato assinado com a autoridade pública. Um dos exemplos mais significativos do Estado promotor de infra-estrutura é, sem dúvida, o serviço de abastecimento de águas e criação de redes de esgotos para a cidade de São Paulo.

A questão da água para abastecimento da cidade era um tema muito presente dentro do debate político paulistano desde a metade do século XIX. Em 1856, encontramos dois projetos que buscavam aumentar o fornecimento do líquido com novas represas para as águas dos córregos Pacaembu e Reiuno, feitas a pedido do presidente da Província Francisco Diogo Pereira de Vasconcellos (Figura 1). Na década seguinte esse mesmo problema aparece nas páginas do relatório provincial de Antonio Candido da Rocha,

A falta de água potável é, sem contradição, o maior mal de que se ressente esta Capital; a quantidade, que tem sido possível fornecer é insuficiente às necessidades de seus habitantes. [...] As águas dos nossos poucos chafarizes não são de boa qualidade; pelo cômodo e pela facilidade da obtenção, uma grande parte da população usa das águas de cisternas, que são inferiores àquelas, socorrendo-se ainda, mesmo no tempo em que os chafarizes mais abundam, às do rio Tamanduateí, tão saturadas de imundícias (SÃO PAULO, 1870a, p. 47-48).

A questão do abastecimento precário arrastava-se há tempo. Em 1864, o governo provincial havia realizado contrato com F. Ribeiro dos Santos Camargo e Carlos Rath justamente para solucionar o agravamento do problema da distribuição pública da água. Nesse contrato, os empresários comprometeramse a "fornecer diariamente a esta cidade 80,000 medidas d'água". Contudo, o governo constatou irregularidades: "Decorridos, porém, os prazos para o começo e a conclusão das obras, sem que os empresários o tivessem cumprido, apesar do privilégio concedido por 30 anos, e da subvenção de 20:000\$ anuais", fato que o levou a rescindir o contrato. A rescisão teria sido uma iniciativa dos empresários que tomaram conhecimento de seu próprio engano

Quando calcularam que as vertentes ou mananciais do morro Caguassú, que formam os tanques - Municipal e Santa Thereza, poderiam produzir aquela quantidade d'água por dia. E, com efeito, tendo-se ultimamente examinado esses mananciais, verificou-se que a quantidade das águas produzidas por todos eles não passa de 109,780 litros em 24 horas nos tempos ordinários, reduzindo-se no tempo de seca a 68,613 (SÃO PAULO, 1870a, p. 481.

Esse cancelamento deu início a uma nova iniciativa: a de captar água na Serra da Cantareira, pois um estudo preliminar havia sido encomendado pelo governo ao engenheiro escocês James Brunless. Com a Lei n. 72 de 20 de maio de 1866, ficava autorizado o governo provincial de São Paulo a "contratar com quem melhores condições oferecesse, o encanamento das águas 


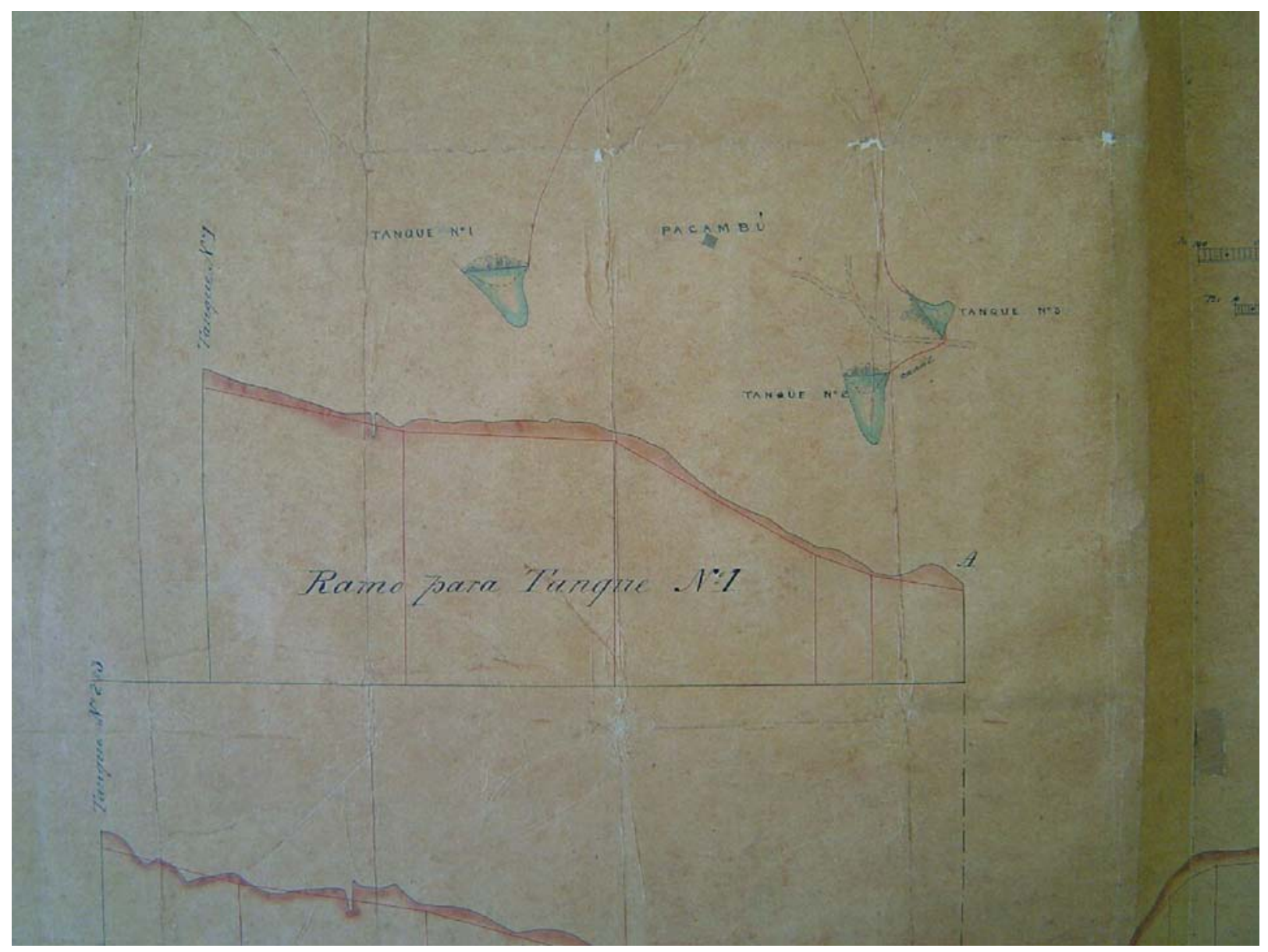

Figura 1 - $\bigcirc$ projeto de encanamento de águas do córrego Pacaembu, realizado em 1856, foi uma das primeiras propostas visando atender à necessidade de novos mananciais para o abastecimento da capital. Detalhe do Plano do projeto de encanamento das águas do Pacaembú para suprir a cidade de São Paulo feito por ordem do Exmo. Snr. Dr. Francisco Diogo Pereira de Vasconcellos, Presidente da mesma Provincia, 1856. Acervo do Arquivo do Estado de São Paulo.

da Cantareira". Segundo essa lei, caberia à empresa interessada a construção gratuita de quatro chafarizes pela cidade, concedendo ainda a renda obtida com a venda da água por 50 anos, sendo que o governo não poderia garantir juros ou dar subvenção. Depois de três anos da publicação da lei, não houve comparecimento de nenhum empresário ou companhia interessados nos serviços. Apresentou-se para execução das obras Thomaz Cochrane, que associado a outros, exigia "garantias e favores", sendo assim negado o pedido (SÃO PAULO, 1870a, p. 48-49). Como não houve nenhuma firma para a execução do serviço, coube ao próprio governo provincial realizar algumas obras de melhoramentos nos chafarizes existentes da cidade. Antonio Candido da Rocha voltou a insistir nesse mesmo relatório quanto à necessidade da construção de novas redes de abastecimento de água mais pura e higiênica do que a elevação e encanamento dos fluidos do Tamanduateí. Sobre a canalização do Córrego da Pedra Branca 
na Serra da Cantareira, defendia o presidente ser essa uma tarefa a ser empreendida pelo Estado:

\begin{abstract}
Despenda-se por uma só vez, embora uma soma avultada, a Província lucrará, e tão palpitante necessidade deixará de existir. Em meu pensar, a empresa pode ser empreendida pelo governo e levada ao cabo sem gravoso ônus ou empenho do Tesouro, uma vez que todos os beneficiados por ela contribuirão para sua sustentação, decretando-se uma distribuição obrigatória pelos prédios, como se pratica em algumas cidades, e como foi determinado no Rio de Janeiro, em favor da Companhia de Esgotos. (SÃO PAULO, 1870a, p.50), (grifo nosso).
\end{abstract}

Nesse mesmo ano, 1870, ao passar a presidência da Província para Vicente Pires da Mota, Rocha anunciou em outro relatório que a Assembléia Provincial autorizara o governo a contratar empresários ou companhias competentes para realizar a canalização das águas da Cantareira. Com a Lei n. 102 de 30 de abril de 1870, o governo provincial passaria os serviços de canalização e distribuição das águas para os prédios públicos e particulares. Assim, o governo publicou editais chamando para as obras, que deveriam "†omar por base os estudos e plantas do Engenheiro Brunlees ${ }^{8}$, autoridade na matéria" (SÃO PAULO, 1870a, p. 13). Ao todo, foram cinco propostas apresentadas ao governo e, sendo de máxima urgência a construção das novas redes para aplacar o problema da falta de água, o presidente Rocha havia contraído um empréstimo de 650:000\$000 de réis para que a obra fosse iniciada. Contudo, Rocha não conseguiu criar uma empresa pública para cuidar do problema de abastecimento, tendo que acatar a decisão de chamar uma empresa privada, cabendo ao seu sucessor a escolha.

No relatório de 1871, o presidente Antonio da Costa Pinto Silva providenciou pareceres sobre as propostas recebidas para as obras da Cantareira. Além do parecer expedido pelo inspetor de Obras Públicas da capital, Luiz Pereira Dias, outro foi dado pelo engenheiro João Martins da Silva Coutinho. Com base nessas duas opiniões, decidiu o presidente não escolher nenhuma das propostas encaminhadas, porque:

1) a de João Francisco dos Reis era cara, reduzia a capacidade da caixa de água e pedia um extenso encanamento que encareceria a obra futuramente;

2) a de Antonio José do Couto previa um pagamento adiantado e a redução do depósito e do diâmetro do encanamento;

3) a do engenheiro Edward E. Benest elevava muito o preço da obra e reduzia a caixa de água pela metade;

4) a de Maximiliano Nothman e do tenente-coronel João Ribeiro dos Santos Camargo eram vagas e por "não precisarem as obras a fazer-se para a execução do plano";
8. James Brunlees (18161892) era engenheiro civil nascido em Kelso, na Escócia. Trabalhou em inúmeras ferrovias no Reino Unido, atuando também como consultor na Channel Tunnel Company (1872-1886), empresa voltada para a construção do primeiro túnel sob o Canal da Mancha, ligando a Inglaterra à França (Gazetteer for Scotland, 2004). O responsável pela sua vinda a São Paulo foi Irineu Evangelhista de Souza, com o objetivo de estudar a viabilidade de construção de uma ferrovia entre Jundiaí e Santos, transpondo a Serra do Mar, aceitando o contrato para a sua construção (SANTOS; LICHTI, 1996). 
9.A proposta de abastecimento pelas águas da Cantareira, feita pelo engenheiro Brunlees, baseouse, segundo Luiz Pereira Dias, da Inspetoria Geral de Obras da Província, em dados superficiais, o que levou o inspetor a pedir em relatório que novos estudos sobre a abundância dessas águas fossem realizadas (SÃO PAULO, 187 0a,p.A4-39)

10. Responsável pela apresentação da proposta para a rede de águas e esgotos de Campinas, em 1879. Em 1880, junto com Antonio Francisco de Paula Souza e Adolpho Augusto Pinto, apresentou a Carta corográfica da Província de São Paulo.
5) as propostas de Augusto Fomm e uma segunda proposta de Benest foram rejeitadas por terem sido apresentadas fora do prazo estipulado (SÃO PAULO, 1871, p. S8-2).

Justificando a negação de todos os projetos, o presidente da Província destaca que ainda seria necessário que outros estudos fossem feitos sobre as águas da Cantareira, como por exemplo, "o conhecimento completo das águas do ribeirão"9 em estações de seca, pois sem esse estudo, "seria um erro determinarse a obra" para o "abastecimento de uma população que aumenta consideravelmente" (SÃO PAULO, 1871, p. 55 e S8-2). Essa ressalva de Silva poderia basear-se nos sérios problemas de abastecimento que a cidade enfrentava desde certo tempo:

Feitos os necessários estudos nesse sentido, para que se possa com segurança confiar no encanamento e na distribuição nunca interrompida de água potável, persuado-me que a obra das canalizações deve ser levada a efeito, porque é uma das maiores necessidades desta importante cidade (SÃO PAULO, 1871, p. 56), (grifo nosso).

Durante o ano de 1871, o governo da Província de São Paulo passou por três presidentes que não fizeram referência ao abastecimento de água de São Paulo em seus relatórios. No ano de 1872, o presidente José Fernandes da Costa Pereira Junior, em exercício desde 30 de maio de 1871, apresenta relatório que descreve a situação da canalização para o abastecimento público. Tinha ele uma idéia diferente de seus antecessores, não compartilhando de uma visão de progresso e desenvolvimento para São Paulo, uma cidade que a seu ver era modesta e não precisaria de vultuosa obra de abastecimento de água, como previa o projeto de Brunlees, 6 milhões de litros em 24 horas, para uma população aproximada de 20 mil habitantes com a quantidade de 300 litros por pessoa (SÃO PAULO, 1872, p. 75). Sendo assim, por não ser um centro urbano de destaque, como Londres ou Lyon, que justificasse tamanha obra, propôs a uma outra comissão a tarefa de verificar os mananciais ao redor da cidade e se eles prestavam para o abastecimento, e justificava:

cumpre notar que esta capital não se acha nas mesmas condições das de muitas das principais cidades da Europa, pois que tem junto a si um rio perene, de águas que, se não podem ser aproveitadas para todos, servem ao menos para quase todos os misteres da respectiva população, ao que acresce que em muitos pontos de sua área encontra-se água potável a pequena profundidade do solo. (SÃO PAULO, 1872, p. 75), (grifo nosso).

A comissão, formada pelos engenheiros J. M. da Silva Coutinho e João Pinto Gonçalves ${ }^{10}$, apresentou suas conclusões com obras que teriam um custo inferior ao da canalização do Ribeirão da Pedra Branca, com a quantidade de três milhões de litros medidos nos ribeirões Camocy, Municipal, Bexiga e Pacaembu, possuindo ressalvas para o Municipal, pois a abundância de suas águas "podiam chegar aos pontos mais altos da cidade, sem o emprego de máquinas de elevação" (SÃO PAULO, 1872, p. 76). 
No seu total, essas obras foram orçadas em 457:174\$538 e incluiriam

\begin{abstract}
o aproveitamento das águas do tanque do Bexiga e ribeirão Municipal, constando as mesmas de uma caixa no alto do Caguassú, suficiente para conter 2,249 litros, de máquinas de elevação, encanamento em toda a cidade, caixa no largo de S. Gonçalo suficiente para 700.000 litros, encanamento do tanque Municipal à mesma caixa, e seis chafarizes. Estas obras asseguraram suprimento de água para 35.000 habitantes, na razão de 84 litros por pessoa em 24 horas (SÃO PAULO, 1872, p. 76).
\end{abstract}

Por outro lado, mesmo justificando a pertinência das obras, esses engenheiros não emitem pareceres sobre a qualidade dessas águas. $\bigcirc$ presidente Pereira Junior não compartilhava da mesma idéia de seus antecessores, talvez por não vislumbrar um desenvolvimento tão rápido para a cidade. Sendo a favor da reforma na repartição de Obras Públicas e defendendo recursos para esses fins, preferiu também poupar os cofres públicos de maiores gastos com o abastecimento da cidade. Mesmo modesta, sua proposta garantia 24 litros per capita a mais, mas para uma população de apenas 35 mil habitantes.

Nesse mesmo ano de 1872, Pereira Junior passou a presidência da Província para o conselheiro Francisco Xavier Pinto Lima. Em relatório, o antigo presidente explicou que foi impedido de realizar grandes obras públicas porque as finanças não o permitiram. Em dezembro de 1872, o conselheiro Pinto Lima passou a presidência para João Theodoro Xavier, e em seu relatório de troca de governo nota-se sua preocupação com questões ligadas à higiene e à saúde pública, em especial com o abastecimento, sendo que mesmo sem recursos para as obras, quis deixar algumas considerações sobre o assunto ao seu sucessor. Se na administração de Pereira Júnior houvera rejeição da captação de águas da Cantareira, Pinto Lima defenderia as obras do Ribeirão da Pedra Branca. Sobre a água que abastece a cidade, armazenada no tanque municipal, comenta: "não considero como água potável a impura e insalubre do rio Tamanduateí, que pode apenas prestar-se a lavagem". Argumenta ainda que a cidade não aproveita de outros mananciais, agravando assim o problema da falta de água, fazendo com que aparecessem vários projetos, entre eles o de canalização das águas da Cantareira" as quais, pela sua pureza e abundancia" poderiam "amplamente satisfazer as necessidades públicas".

Citando ainda governos anteriores, o conselheiro afirmava que várias propostas foram apresentadas e recusadas por serem "deficientes ou onerosas", e que naquele ano, outras três novas propostas haviam sido entregues à Assembléia Legislativa Provincial, que as passou ao governo provincial e este, por sua vez, as entregou à Câmara Municipal para realizar contrato com um dos empresários. Contudo, como estava sujeito "à aprovação da mesma assembléia, deu a Presidência o devido cumprimento a esta deliberação, transmitindo as propostas à Câmara, a qual resolveu não usar da autorização que the fora conferida, limitando-se a examinar as propostas" (SÃO PAULO, 1872, p. 27-28). As propostas apresentadas foram de Andrade \& Santos, do tenente-coronel Lindoro José Branco e a do capitão Henrique Luiz de Azevedo 
Marques. A Câmara acabou por optar pela proposta de Lindoro, e, ao que parece, o governo provincial ficou fora dessa tomada de decisão entre a Câmara e a Assembléia.

Em 1874, João Theodoro cobrou da assembléia uma posição concreta sobre o problema do abastecimento, pois propostas foram apresentadas e discutidas, mas nenhuma decisão foi tomada. Assim sendo, o presidente remontou à Lei n. 102 de 1870 e disse que não entende como conveniente o seu uso, já que a assembléia estava discutindo novos projetos. Reiterou, então, a urgência da situação, alegando que "duas grandes freguesias da Capital", Brás e Santa Ifigênia não estavam recebendo água, e a população "sujeitava-se ao uso de águas de má qualidade" (SÃO PAULO, 1874, p. 12). Ao que tudo indica, a assembléia não havia se decidido sobre qual projeto de abastecimento de água deveria escolher para São Paulo. Parece-nos que essa lentidão teria levado o governo provincial a tomar medidas próprias, dentro do seu alcance e competência para solucionar o problema da falta de água com a construção de novos chafarizes, preocupando-se em utilizar vertentes d'água de boa qualidade para consumo (SÃO PAULO, 1875, p. 123).

Quando passou a presidência para Joaquim Manoel Gonçalves de Andrade, João Theodoro explicou que o governo provincial havia publicado editais chamando para a canalização das águas da Cantareira, medida essa que deve ter sido tomada por causa da falta de postura da assembléia. Uma dúvida, porém, permanece: a Lei n. 102 de 1870, que estabelecia a cobrança de um imposto para a execução das obras da Cantareira, foi suspensa ou estava sendo cobrada dos munícipes? Parece-nos que a lei havia sido recusada, mas um relatório de 1875 traz uma manifestação da Câmara Municipal sobre um imposto que vinha sendo recolhido para as obras de canalização "fazendo ver quão onerada de imposições já se achava a população, reclama contra o imposto predial de 5\% sobre o aluguel das casas [...] para ocorrer ao pagamento desse compromisso" (SÃO PAULO, 1875, p. 7). Essa afirmação nos leva a supor, muito provavelmente, que desde 1870, esse imposto era recolhido para uma obra que não havia sido definida cinco anos depois da promulgação da lei!

\section{A produção privada do saneamento: a Companhia Cantareira \& Esgotos}

A idéia de contratação de uma firma para realizar as obras de canalização e distribuição das águas da Cantareira começou a ganhar mais força a partir da metade da década de 1870. O governo provincial, durante o ano de 1875, foi tumultuado, pela troca de presidente, fato que contribuiu para uma não resolução definitiva do problema do abastecimento. A transição para um governo mais estável demorou alguns meses para firmar-se. Em 8 de junho de 1875 tomava posse Sebastião José Pereira, que no relatório de 1876 voltaria à delicada questão da água, afirmando que "era incontestavelmente a necessidade mais palpitante desta Capital". Percebe-se em sua fala uma crítica 
à utilização das águas próximas à cidade, talvez fazendo referência à proposta do presidente José Fernandes da Costa Pereira Júnior.

Como o problema vinha sendo empurrado desde o início da década, coube ao governo provincial tomar a iniciativa:

Se não é permitido dizer-vos hoje como em 1834 dizia a municipalidade de Marselha sobre assunto igual: - "custe o que custar, suceda o que suceder, o encanamento se há de fazer" -, posso comunicar-vos que o contrato para a canalização das águas da Cantareira está efetuado com os Srs. Coronel Antonio Proost Rodovalho, Major Benedito Antonio da Silva e Daniel M. Fox, cavalheiros bem conhecidos como incapazes de faltarem à palavra prometida (SÃO PAULO, 1876, p. 4-5), (grifo nosso).

A contratação desses empresários para a execução das obras valeuse da Lei n. 102/1870. Já que, aparentemente, não houve a apresentação de outros empresários interessados em contratar os serviços, o presidente da Província acabou por decidir-se pelo projeto de Rodovalho e seus sócios. Dúvidas sobre esse episódio ficam no ar: o que teria sido feito com o dinheiro que vinha sendo recolhido desde 1870 para as obras de canalização? Foi utilizado para outro fim ou foi entregue a esses empresários? A Província acabou por contrair o empréstimo de $6.000 \$ 000$ para financiar a obra? Neste relatório, Sebastião José Pereira desenvolve longa explanação defendendo o projeto de Rodovalho e sócios, buscando opiniões de outros profissionais sobre o abastecimento de água em cidades brasileiras como Recife, e em países como a Inglaterra e Estados Unidos, cujos serviços de fornecimento são executados por empresas particulares. No contrato feito com a Província "a empresa tem o direito exclusivo de vender água por 70 anos, ao preço máximo de 1 real o litro, sendo a água levada por meio de encanamento à habitação do comprador" (SÃO PAULO, 1876 , p. 6). Caso não houvesse interesse em comprar a água desses empresários, - líquido poderia ser consumido gratuitamente nos chafarizes públicos existentes ou nos que seriam instalados pela própria companhia. Não seria vetado, porém, como em outras cidades brasileiras, a utilização de águas de córregos e ribeirões, reitera Pereira nesse relatório. Um dado curioso que deve ser por nós destacado é o fato de Pereira não exigir, ao que tudo indica, um estudo da abundância das águas do Ribeirão da Pedra Branca em época de estiagem, fator que levou o presidente Antonio da Costa Pinto Silva a recusar, em 1870, todas as propostas para o abastecimento de águas da capital.

O contrato entre o governo provincial e a futura Companhia Cantareira foi celebrado em 9 de outubro de 1875, assinado pelo presidente Sebastião José Pereira e os empresários Antonio Proost Rodovalho, Benedicto Antonio da Silva e Daniel Makinson Fox"1, aqui representado pelo seu procurador Joseph Bryan. Com esse ato, os empresários, que estavam contratando a "canalização das águas da Cantareira e sua distribuição pelas ruas e praças" de São Paulo, deveriam construir as obras de canalização e distribuição em "conformidade com o plano e desenhos que exibirão", mas os projetos deveriam ser um "melhoramento" daquele já apresentado pelo engenheiro Brunless. Quanto às obras, o contrato estabelecia que deveriam ser construídas
11. Daniel Makinson Fox era engenheiro e trabalhou na São Paulo Railway Co., escolhido por Irineu Evangelista de Souza para realizar a construção dessa ferrovia, pois "havia adquirido seus conhecimentos na construção de estradas de ferro através das montanhas do norte do País de Gales e das encostas dos Pirineus" (SANTOS; LICHTI, 1996). 
duas presas de água com tanques ou reservatórios de acumulação e de clarificação, com capacidade de cerca de 50.000.000 de litros, bem como dois reservatórios cobertos, construídos de beton, tijolos e cimento, de capacidade de 6.000.000 de litros, colocados em altura própria para forçar a água por cima do edifício mais alto da capital. (RELATÓRIO, 1876, s 1-11

Nos reservatórios de distribuição, os canos teriam o diâmetro de $305 \mathrm{~mm}$, e os tubos saídos do reservatório, $381 \mathrm{~mm}$, diminuindo depois para 70 mm, sendo todo esse em ferro fundido. Para a distribuição pública de água, os empresários ficariam incumbidos de construir mais seis chafarizes pela cidade, contendo quatro torneiras e uma cisterna interna. Os lugares que receberiam chafarizes públicos seriam determinados pelo próprio governo. Além desses pontos de distribuição gratuita, os empresários deveriam disponibilizar à cidade cem válvulas de incêndio (SÃO PAULO, 1876, p. S1-1).

Ainda caberia aos empresários fornecer água para edifícios públicos (provinciais e municipais) pela metade do preço cobrado aos usuários particulares. Por sua vez, o Estado não seria obrigado a financiar as obras, uma vez que o contrato estabelecia que "não receberão quantia alguma dos cofres, nem a título de subvenção ou garantia de juros, ou qualquer outro", sendo que em contrapartida "fica-lhes garantido o direito exclusivo de durante 70 anos vender água aos particulares e aos estabelecimentos públicos" (SÃO PAULO, 1876, p. S1-3). Completados os 70 anos, toda a estrutura montada pelos empresários para o serviço de abastecimento da cidade seria entregue ao Estado, sem ônus algum.

O governo provincial facilitaria, segundo o artigo 19, a importação de materiais para as obras, com a isenção de impostos municipais e gerais, inclusive intercedendo junto às estradas de ferro para cobrarem tarifa diferencial por ser essa uma obra de interesse público. Quanto ao uso da água, o contrato impede a comercialização do líquido por um preço maior que o estipulado no artigo 13, que é de um e meio real o litro. Além desse limite para a cobrança da água encanada, ficou aqui estabelecido que os habitantes não eram obrigados a comprar a água dos empresários, podendo se servirem nos chafarizes públicos ou mesmo em outras fontes, conforme o artigo 14:

Fica mantido ao público o livre uso e gozo dos rios, ribeiras, tanques e vertentes atuais, e bem assim aos particulares o das fontes, depósitos, poços e mananciais que possuírem. Não poderão, porém, haver outros chafarizes ou depósitos alimentados por encanamentos diverso do da Cantareira (SÃO PAULO, 1876, p. S1-3).

Segundo o artigo 16, as obras de abastecimento deveriam começar dentro de um prazo de 24 meses, a contar pela data desse contrato, sendo concluídas em 18 meses, contados a partir do início das construções, cabendo aos empresários comunicar o dia de início dessas obras. Para a fiscalização, segundo o artigo 25, os empresários deveriam manter um engenheiro fiscal, que reportaria ao governo provincial o andamento e as características gerais das obras, sendo que os seus vencimentos seriam cobertos pela própria empresa (SÃO PAULO, 1876 , p. S 1-4-5). 
Esse contrato, assinado entre Antonio Proost Rodovalho, Benedicto Antonio da Silva, Joseph Bryan (procurador de Daniel M. Fox) e o presidente da Província Sebastião José Pereira, porém, não conseguiria desencadear as obras de abastecimento, passando ainda por outras reformulações e adequações em 7 de abril de $1877^{12}$ e em 8 de abril de 1879. A reformulação do contrato pode ter ocorrido com base em um acordo entre ambas as partes, já que Rodovalho e sócios não haviam começado as obras, sob pena de multas segundo o contrato anterior. Uma motivação para a alteração do contrato anterior deve ter sido a organização de Rodovalho e sócios para a criação da Cantareira \& Esgotos, em 1877, uma empresa que contava com capitais nacionais e estrangeiros. Com a empresa, houve também a abertura para a entrada de novos acionistas ("chamada de capitais") e a inclusão dos serviços de coleta de esgotos (BRITO, 2000; OSEKI, 1992), mas com poucos detalhes, inclusive nos contratos analisados, de como seria construída essa rede.

Após as alterações dos contratos acima referidos, ocorreu um terceiro contrato, assinado em 8 de abril de 1879, celebrado entre o então presidente da Província Laurindo Abelardo de Brito e a diretoria da empresa, ali representada pelo seu presidente Clemente Falcão de Souza Filho e outros membros da diretoria como o barão de Três Rios (Joaquim de Souza Aranha) e Raphael Aguiar Paes de Barros ${ }^{13}$. Foram poucas as modificações feitas nesse terceiro contrato. $O$ artigo $1^{\circ}$ esclarece que nem todos os chafarizes da cidade seriam de responsabilidade da companhia, deixando claro que o Estado ainda seria o responsável por parte do abastecimento. É reforçado, ainda, o monopólio que a companhia manteria na distribuição de água da cidade, com certo controle, inclusive, na criação de novos chafarizes. $\bigcirc$ artigo $3^{\circ}$ estabelece que tanto os encanamentos de distribuição de água como o de coleta de esgotos deveriam ser entregues no dia 30 de junho de 1881, dando assim à empresa um prazo maior para a conclusão das obras, do que aquele estipulado pelo primeiro contrato. A última consideração interessante, o artigo 4ㄴ, menciona que estão "revogadas as estipulações dos referidos dois contratos que não se harmonizarem com as que neste ficarão consignadas, e em pleno vigor todas as mais". Essa colocação evidencia que os contratos anteriores estabelecidos com o governo provincial paulista tiveram um valor legal.

Após a assinatura desse contrato definitivo para o começo das obras da companhia, são escassas as notícias sobre o seu andamento nos relatórios provinciais. No relatório seguinte, do ano de 1877, Pereira não teceu nenhum comentário sobre a empresa e nem sobre o andamento dos serviços. Referências às obras apareceriam no relatório de 1880, dentro da seção destinada à Repartição de Obras Públicas. $\bigcirc$ presidente Laurindo Abelardo de Brito, comentando sobre a inauguração dos trabalhos do reservatório de distribuição de águas da Consolação, em setembro de 1878, disse que a diretoria da Companhia Cantareira aproveitando a visita do imperador Pedro II, colocou a pedra fundamental dessa obra. Segundo o relatório, essas obras vinham ocorrendo com "bastante morosidade atento o atraso em que se achavam todos os planos necessários para a construção das obras" (SÃO PAULO, 1880, p. 135-136).
12. Não foi possível localizar esse contrato de 7 de abril de 1877 .

13.A Cia. Cantareira \& Esgotos contava com outros acionistas. Entre eles destacamos: Clemente Falcão de Souza Filho, Domingos de Moraes, Paulo E. de Oliveira Carvalho, Olavo Egídio de Souza Aranha, Olavo Paes de Barros, L. O. Lins de Vasconcellos, M. J. Albuquerque Lins, A. A. Monteiro de Barros, Carlos de Campos, Eleutério da Silva Prado, Elias Fausto Pacheco Jordão,Antonio de Pádua Salles, Gabriel Dias da Silva, William Speers, Domingos Sertório (BRITO, 2000, p. 24) 
Os reservatórios, segundo o contrato de 9 de outubro de 1875 , deveriam abrigar a quantidade de 600 metros cúbicos, mas essa capacidade seria aumentada. Baseando-se nesse montante, o volume de água fornecido pela Cantareira seria de 2.970.007 litros, distribuídos para uma população de 30.870 habitantes, fornecendo assim a quantidade de 95 litros por dia para cada pessoa. $\bigcirc$ presidente Brito mostrou o seu desconforto com esses números, argumentando que essa quantidade ficaria "muito abaixo dos principais misteres domésticos, se atendermos que os especialistas em tais matérias marcam como limite mínimo para os usos domésticos e lavagem dos esgotos, 100 litros por pessoa e por dia". A seu ver, isto provaria

a insuficiência dos mananciais, e quando o governo no contrato celebrado com a companhia em outubro de 1875, estipulou que o menor reservatório conteria capacidade para 6.000.000 de litros, foi já prevendo um desenvolvimento futuro e não muito remoto que pudesse ter esta capital, por que neste caso cabendo 200 litros de água por habitante e por dia, restava ainda uma larga margem para a população dupla da atual, visto como obras dessa natureza que demandam grandes capitais devem ser realizadas com vistas de não restringirem os benefícios que trazem à salubridade pública, em um dos seus principais elementos de vida como é o abastecimento de água potável (SÃO PAULO, 1880, p. 136), (grifo nosso).

Esse trecho evidencia como Brito, assim como alguns outros presidentes anteriores, colocava em dúvida o potencial de fornecimento de água para uma cidade que crescia a cada dia. Brito prosseguiu a sua descrição das atividades da companhia, afirmando que todo o material para as obras já havia sido encomendado na Inglaterra. Esse material consistia em " 45 toneladas de chumbo para as juntas dos tubos, $1 / 2$ tonelada de estopa para o mesmo fim, 750 barricas de cimento, 3.180 tubos para encanamento com 0,305 de diâmetro" (SÃO PAULO, 1880, p. 137).

Haviam sido aprovados pelo governo provincial as plantas e perfis da construção das redes de águas e de esgotos (Figura 2); em 17 de abril de 1879, a localização dos chafarizes e em 4 de setembro, a localização das válvulas de incêndio, em conformidade com as cláusulas $4^{\underline{a}}$ e $6^{\underline{a}}$ daquele contrato. Brito também mencionou uma outra atividade a qual Companhia Cantareira \& Esgotos estaria se dedicando, além das redes de águas e esgotos:

A diretoria da companhia, compreendendo que as condições de salubridade pública da capital não eram só dependentes do abastecimento de água potável e de um bom sistema de esgotos, mas também de uma perfeita dessecação dos seus pântanos, mandou proceder a estudos neste sentido, que revelarão ser possível evitarem-se as enchentes que anualmente proporcionam os rios Tamanduateí e Tietê. A companhia não está obrigada por contrato a esse serviço e por isso mesmo é digno de louvor o seu procedimento. (SÃO PAULO, 1880, p. 137)

Para finalizar sua fala sobre os trabalhos da companhia, Brito recomendou que o poder público acompanhasse os trabalhos desenvolvidos por 


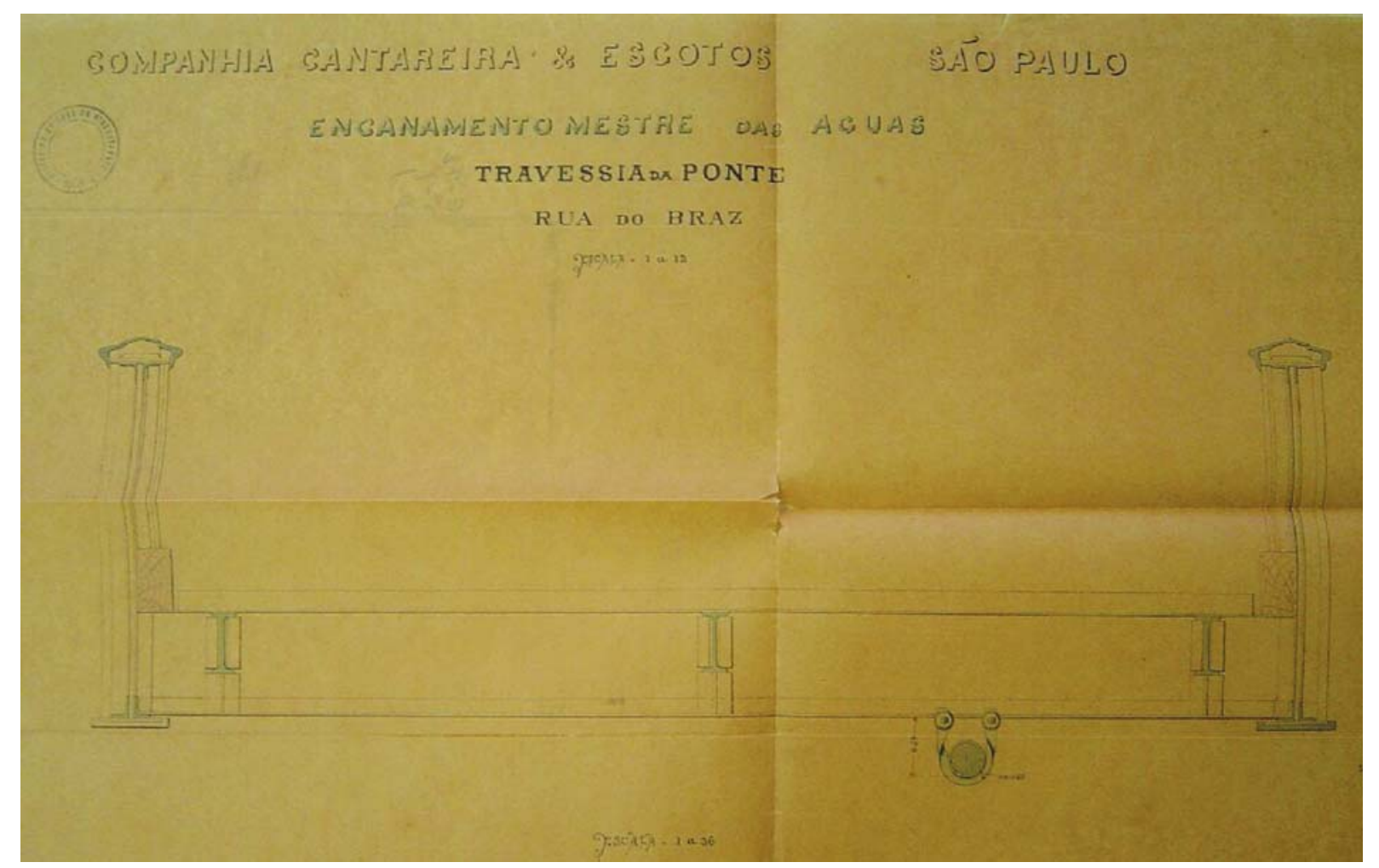

Figura 2 - A Companhia Cantareira detalhou os pontos por onde passariam os encanamentos mestres vindos da Serra da Cantareira, responsáveis por abastecer os reservatórios da cidade. Encanamento Mestre das Águas - Rua do Brás. Original da Companhia Cantareira e Esgotos. Acervo do Arquivo do Estado de São Paulo.

ela ${ }^{14}$, porque eram desses serviços que dependiam "a saúde e a vida dos habitantes desta florescente capital" (SÂO PAULO, 1880, p. 137).

Como o último contrato de 8 de abril de 1879 colocava que a Província deveria se responsabilizar pelos seus próprios chafarizes, nesse mesmo relatório de 1880, na exposição da Diretoria Geral de Obras Públicas (cujo diretor era o engenheiro Antonio Candido Rodrigues), apareceram notícias sobre o antigo sistema de abastecimento da capital. Segundo o secretário interino dessa diretoria, José Custódio Alves de Lima, o serviço de abastecimento vinha sendo feito com regularidade, tendo sido prejudicado apenas pela longa estiagem que atingiu a cidade, causando algumas irregularidades nos reservatórios, cabendo à diretoria "fazer as despesas necessárias com as desobstruções e abaixamento do nível dos tubos em uma pequena extensão, a fim de aproveitarse a água do tanque que existia em pequena quantidade, ficou logo sanado aquele mal", não faltando o líquido nos reservatórios e depósitos da cidade (SÃO PAULO, 1880, p. A $13-5$ ).

Entre 1880 e 1881, o governo provincial e a Companhia Cantareira fecharam os seguintes acordos:
14. Segundo o contrato de 9 de outubro de 1875 , a empresa deveria manter um engenheiro fiscal para informar sobre $o$ andamento das obras ao governo provincial. O relatório de 1882 aponta que esse engenheiro fiscal havia sido Adolpho Augusto Pinto, que desempenharia papel fundamental dentro da Companhia Paulista de Estradas de Ferro. Esse mesmo relatório reconhece o trabalho desenvolvido por esse engenheiro e afirma que ele "continuará a merecer a confiança do governo" (SÃO PAULO, 1882,p.44). 
- Ato de 8 de janeiro, que declarava de utilidade mista municipal e provincial os terrenos da Serra da Cantareira e do Morro de Santana, porque a companhia iria utilizá-los em suas obras.

- Despacho de 6 de abril, que aprovava os seis desenhos de chafarizes propostos pela companhia.

- Despacho de 10 de maio que não aprovava os planos para utilizar a estrutura da Ponte Grande e outras duas pequenas no aterrado de Santana para suportar os encanamentos que levariam a água até a cidade. Segundo esse relatório, as pontes não suportariam demasiado peso.

- Alteração dos contratos de 1875 e 1877 realizada em 8 de abril de 1879 que estipulava a conservação dos chafarizes públicos e a concessão de água para a Santa Casa de Misericórdia, concedendo o governo à companhia "como compensação, a prorrogação do prazo para a conclusão das obras até 30 de junho do corrente ano".

- Novas chamadas de capitais para a companhia foram anunciadas, no valor de $200 \$ 000$ réis, divididos em 11 mil ações (SÃO PAULO, 1881 , p. 70), (grifo nosso).

andamento das obras é descrito pelo engenheiro fiscal em exercício, Adolpho Augusto Pinto, e reproduzido no relatório provincial pelo secretário da Repartição de Obras Públicas, José Custódio Alves Lima. Lima explicou que a localização dos chafarizes a serem instalados pela companhia ficara definida para Guaianazes, Sete de Setembro, São Bento, Luz, Curros e Brás, sendo ainda instaladas mais cem válvulas de incêndio em cada quarteirão da cidade. $O$ reservatório de distribuição, relatou o engenheiro, tinha uma capacidade de três milhões de litros, fornecendo a quantidade de cem litros por pessoa para uma população de 30 mil habitantes, medida inferior se compararmos com as propostas apresentadas anteriormente. Por último, relatou que as águas da Cantareira satisfaziam "as condições de salubridade exigidas pelos higienistas" (SÃO PAULO, 1881 , p. 73).

Assim, uma parte das obras de abastecimento foi entregue dentro do prazo, em junho de 1881, mesmo ano em que a companhia encomenda uma planta cadastral da cidade (Figura 3). No relatório de 1882, justificando a entrega parcial, o presidente da Província e também membro da diretoria da companhia, conde de Três Rios, expos que a empresa passava por dificuldades em sua chamada de capitais, pois "o capital tem sido realizado sobre um número de ações que está muito longe de atingir ao número primitivamente subscrito", sendo obrigada a recorrer "a outra fonte de recursos para não interromper os seus trabalhos", contraindo um empréstimo em Londres no valor de 1.200:000\$000. Apesar da dificuldade financeira, as obras seguiam para a sua conclusão, com destaque para o viaduto que suavizaria "a influxão rápida das vertentes opostas", um dos reservatórios de recepção estava quase pronto e 


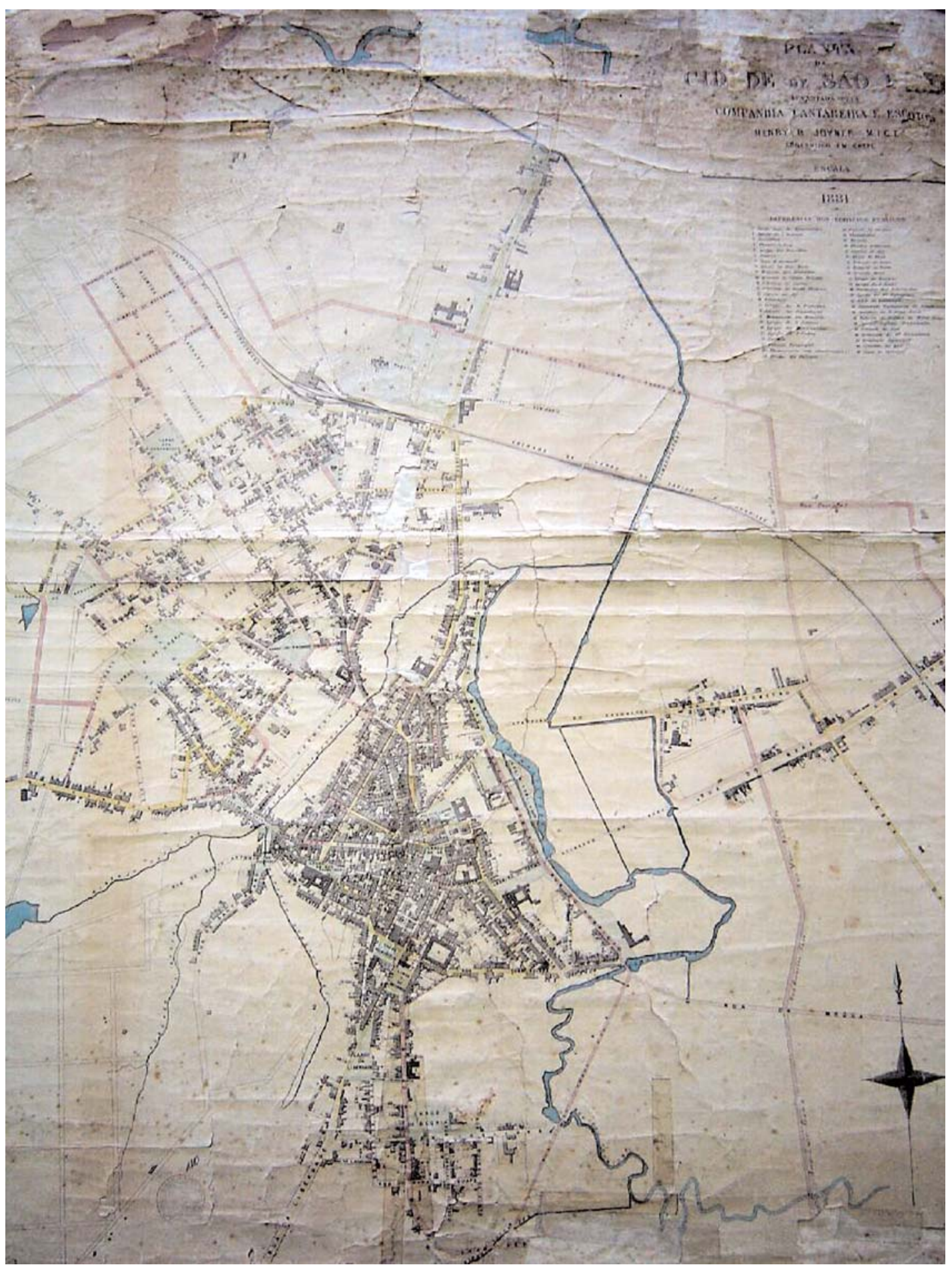

Figura 3 - Além dos acordos firmados entre o governo provincial paulista e a companhia, coube a esta a realização de uma planta cadastral da cidade, mostrando seus principais arruamentos e edificações e evidenciando os principais locais que receberiam novas redes. Planta da cidade de São Paulo levantada pela Companhia Cantareira e Esgotos, 1881. Acervo do Arquivo do Estado de São Paulo. 
15.Segundo o Dicionário Aurélio, pena d'água era uma "antiga medida usada em partilhas de água, da grossura, aproximadamente, de uma pena de pato" e também "taxa fixa paga pelo fornecimento de água aos prédios, inde pendente da quantidade consumida". Segundo Azevedo Neto (apud VILAR, 2003, p. 92) "a história da 'pena d'água'é curiosa, pois originalmente, a unidade de medida para os condutos de água era representada por um orifício de um palmo de circunferência denominado manilha. A manilha era subdividida em dezesseis anéis e cada anel correspondia a oito penas, resultando para a pena de água o diâmetro de $6 \mathrm{~mm}$ ". o segundo "em via de execução". Já os reservatórios de distribuição para serem concluídos necessitavam apenas da cobertura de suas caixas (SÃO PAULO, 1882, p. 431.

Quanto aos equipamentos que deveriam ser instalados pela Companhia, os seis chafarizes foram colocados e dos cem hidrantes, 97 já haviam sido postos. Para a distribuição privada de água em domicílios, a companhia adotou o sistema de "pena d'água"15 e quanto à tarifação decidiu que os preços do fornecimento do líquido deveriam ser aprovados pelo governo, tarifa essa que seria vantajosa para os consumidores, se comparado ao preço de outras empresas do país. Esse relatório também menciona o andamento das obras de implantação da rede de esgotos, com base nas informações passadas pelo engenheiro fiscal Adolpho Augusto Pinto. Se por um lado, o abastecimento aparentemente não enfrentava dificuldades, o mesmo não podia ser dito para a rede de esgotos. $\bigcirc$ encanamento mestre, "desde a sua desembocadura no rio Tamanduateí, proximamente ao Tietê até a Rua do Hospício" já havia sido assentado, sendo que o estava também "o encanamento secundário para servir o bairro do Brás até o Tamanduateí; o que segue à margem do Anhangabaú até a ponte da Rua do Senador Florêncio". Sobre os outros trechos:

Acha-se mais assentado o coletor parcial que passa pela ladeira do Porto Geral e iniciada a colocação do coletor que passa pela Rua Municipal. Dos encanamentos que formam a rede propriamente urbana, acham-se já assentados alguns trechos nas ruas da Boa Vista, Imperatriz, Comercio e algumas travessas, tendo sido ao mesmo tempo levadas ao interior dos prédios as ramificações correspondente (SÃO PAULO, 1882, p. 44).

A questão principal, no relatório de 1883, ainda era a rede de esgotos, que aparece no relatório do vice-presidente visconde de ltu. Segundo esse documento, o governo enviou ao engenheiro fiscal "a demarcação da órbita apresentada pela Câmara Municipal, compreendendo nela os prédios sujeitos às disposições do contrato de 7 de abril de 1877, para o serviço de esgotos", evidenciando assim que parte das ligações de esgotos não havia sido realizada, fato que levou a diretoria da companhia a pedir prorrogação do prazo de entrega da rede, que deveria ser concluída, pelo Ato de 2 de abril de 1883, até outubro desse mesmo ano. A demora no estabelecimento dos serviços levaram o governo provincial a obrigar a companhia a entregar ao uso público "com caráter provisório, o serviço de encanamento de esgotos" em determinados distritos da cidade "ficando além disso [...] obrigada a fazer as lavagens necessárias nos condutores principais e a desinfetar convenientemente todas as entradas do encanamento" (SÃO PAULO, 1883b, p. 19). Mesmo com os atrasos na rede de esgotos, as obras da Companhia Cantareira foram dadas como concluídas pela empresa em 26 de outubro de 1883, mas, para o governo provincial, foram aceitas em caráter temporário, devendo ainda cumprir no prazo de três meses algumas obrigações apontadas pelo engenheiro fiscal (SÃO PAULO, 1884, p. 77).

Quanto aos serviços provisórios de abastecimento de água, transcorreram regularmente, ocorrendo uma redução de $60 \%$ no valor cobrado pelo líquido na tabela aprovada pelo governo, cujo preço máximo permitido 
era "de um e meio real o litro". Mesmo com o preço reduzido, a água era uma mercadoria cara, que não estava ao alcance da população mais pobre da cidade. Esse problema é apontado na própria fala do presidente, Antonio Raiol, o barão de Guajará:

Quanto aos sistemas postos em prática para a distribuição d'água nos domicílios, nenhum deles satisfaz as classes menos favorecidas de recursos por serem mui dispendiosas, quer o sistema de penas, quer o de hidrômetro, até hoje empregados. Este assunto é minuciosamente tratado em seu relatório pelo engenheiro fiscal, que apresentou meios no sentido de oboviar [sic] o inconveniente não conjurado pelos sistemas estabelecidos para distribuição d'água (SÃO PAULO, 1883 b, p. 77).

Outro assunto tratado por Antonio Raiol merece nossa consideração pela atualidade da questão sobre a preservação das matas ciliares de fontes de abastecimento: "São também dignos da vossa consideração a matéria relativa aos mananciais d'água potável e as medidas que convém tomar - coutamento [sic] das matas e arboricultura - para manter e reforçar o suprimento daqueles". Sobre os esgotos, todos os distritos que compõem o sistema geral foram entregues em caráter provisório em 1883. Foi explicado também como funcionaria a taxa que o governo deveria repassar para a companhia ou o encargo que passava dos cofres públicos para a empresa. Ainda relativo aos esgotos, a companhia propusera-se a construir gratuitamente oito mictórios públicos, que tiveram seus pontos de instalação, bem como os desenhos, aprovados pela Câmara Municipal, deliberando ainda a construção de mais oito desses equipamentos na cidade.

Percebemos aqui uma ampliação da esfera de atuação do engenheiro fiscal (ao que tudo sugere, Adolpho Augusto Pinto), que além de fiscalizar contribui para o melhoramento desses serviços. Muitas de suas sugestões foram acatadas, principalmente pela esfera pública. Além da proposta de alteração de cláusulas do contrato, sugeria medidas higiênicas relativas ao sistema de esgotos "para que o serviço [...] seja convenientemente feito, torna-se necessário que o sistema adotado, por melhor que seja, se alie [a] um severo regime higiênico, tendo-se muito em vista as condições de lavagem e ventilação da rede subterrânea". Tocado pela questão da salubridade urbana com a implantação de um sistema de coleta até então inédito, o presidente fez o seguinte apelo à Assembléia Legislativa: "Espero que este assunto merecerá toda a vossa atenção, fazendo adotar tudo o que for exigido para que o serviço de esgotos se faça nas melhores condições higiênicas possíveis, as quais, desprezadas, muito poderá ficar comprometida a salubridade desta capital". O sistema de esgotos deveria ainda ser regularizado pela Câmara Municipal da cidade, de acordo com o contrato, para "regular o uso dos esgotos por parte dos particulares, decretando as medidas convenientes a fim de serem punidas as pessoas que cometerem abusos nos despejos dos prédios" (SÃO PAULO, 1884, p. 78).

Esse debate evidencia que não haviam sido definidas as regras de instalação dessa rede na cidade. Contemplando esse problema, em 29 de setembro de 1883, foi apresentado um Projeto de Posturas Municipais Relativas ao Serviço da Companhia Cantareira \& Esgotos, de autoria do médico da Câmara Municipal 
de São Paulo, Eulálio da Costa Carvalho. O projeto possui ao todo 13 artigos, que dispõem sobre as normas de uso desse sistema até então novo na cidade. Resumidamente, as disposições dizem respeito à obrigatoriedade do uso do sistema onde ele estiver disponível, sendo os proprietários forçados a ladrilhar estábulos, lavanderias; extinguir latrinas e sumidouros, inclusive as latrinas de uso coletivo ligadas a um único tubo, geralmente presentes em cortiços; obstruir os canos que dão para as galerias de águas pluviais, para que não seja realizado nelas nenhum tipo de despejo; prover os prédios de água para a limpeza dos tubos de esgotos; permitir a entrada dos funcionários da companhia para instalação dos tubos de esgotos e manter a limpeza nessas áreas e objetos. Nos outros artigos, são estabelecidos a responsabilidade pela limpeza das redes por parte da companhia, o valor da multa sobre a empresa, em caso de inundação "resultantes de defeitos nas obras", em 20\$000 por praça e rua atingidas, e por último destacamos ainda a incumbência da Câmara Municipal em manter um fiscal especialmente para inspecionar a rede de esgotos da cidade (CARVALHO, 1937, p. 497-499). Esse documento foi enviado ao presidente da Província e aos vereadores da Câmara Municipal, mas não sabemos se, de fato, foi aprovado e colocado em prática.

Para finalizar a rede de esgotos, o governo acaba por conceder uma prorrogação de prazo até o dia 30 de outubro de 1883, por meio do Ato de 2 de abril desse mesmo ano. Em 1884, pelo Ato de 6 de maio, com base nos pareceres enviados pelo engenheiro fiscal e pelo inspetor do Tesouro Provincial, o vice-presidente da Província Luiz Carlos d'Assumpção prorrogou por três meses - prazo de conclusão das obras da Companhia Cantareira, contados a partir do dia 12 de março. Assumpção também autorizou a cobrança da taxa de esgotos, de acordo com as Leis n. 45 de 20 de abril de 1875 e n. 34 de 20 de março de 1876, e em 9 de junho, acabou por autorizar a cláusula $20 \S 4$ do contrato de 7 de abril de 1877, que obrigava o governo a pagar à companhia a metade das taxas de esgoto. Era de responsabilidade do Estado cobrar os proprietários de imóveis que ligaram seus esgotos à rede da Companhia Cantareira. Por atraso ou morosidade do Estado, essa cobrança demorou a ser efetuada, levando o governo a descumprir o seu acordo com os empresários. Alguns membros do governo, como o presidente José Luiz de Almeida Couto, em relatório de 1885, expressa o seu desconforto com o pagamento da taxa e os serviços prestados pela companhia. Depois dessa crítica, Couto relata como ocorreu o abastecimento de água na cidade, dizendo que o mesmo vinha sendo feito regularmente e com asseio, por meio do sistema de hidrômetro. Sobre o consumo, explica que entre janeiro de 1882 e dezembro de 1883, quando funcionava o sistema de abastecimento provisório, os pedidos de ligação de água não passaram de 600, mas que no último ano os pedidos aumentaram para 1.400, todos feitos por meio do sistema de hidrômetro.

Já o sistema de esgotos, inaugurado em 1882, vinha funcionando de forma regular em todos os distritos, desde a canalização central até os coletores secundários, estando ligados a essa rede 4.003 prédios. Após relatar como andavam os serviços, o presidente Couto deteve-se na questão do pagamento das taxas. Citando o contrato e a lei que permitia a cobrança, disse 
que a empresa havia remetido ao governo o número de prédios em que o sistema de esgotos funcionou para receber em fevereiro do corrente ano o valor correspondente por essa coleta. $O$ pagamento semestral, que deveria ser efetuado pelo governo em benefício da companhia, havia sido finalmente resolvido. $O$ impasse em torno do pagamento teria ocorrido pela falta de arrecadação por parte da Província. O acordo entre ambas as partes reconhecia a obrigação do contratante, ficando "sem efeito" as outras instruções expedidas, sendo que a Coletoria já estava realizando o recolhimento das taxas referentes aos "meses de julho e dezembro do ano passado" (SÃO PAULO, 1885, p. 107).

Nesse relatório de 1885, o presidente José Luiz de Almeida Couto teceu outras considerações sobre os esgotos da cidade de São Paulo, uma questão que, desde os primórdios da criação da Companhia Cantareira, não aparecia com tanta freqüência, como o abastecimento, mas mostrava-se cada vez mais prioritário. A primeira ressalva recai no "aumento do perímetro do esgoto", que segundo a cláusula 15a do contrato a rede deveria estender-se "a pontos não compreendidos no perímetro demarcado pela Câmara Municipal", incidindo aqui novamente a taxa que a Província deveria repassar à companhia, equivalente a "9\% sobre o capital em que forem orçadas as novas obras" (SÃO PAULO, 1885, p. 107). A canalização seria feita entre a Rua João Theodoro e a travessa do seminário, reforçando a obrigação da Cantareira na execução da extensão da rede. Outro ponto destacado por Almeida Couto dizia respeito ao "saneamento do esgoto", ou seja, sobre a utilização desse por particulares, talvez preconizando o seu uso como adubo para plantações próximas à cidade, como era feito em outras cidades ${ }^{16}$. A Câmara Municipal, que havia marcado o perímetro de abrangência da rede da companhia, também criou posturas para a utilização dos esgotos, cabendo apenas à assembléia aprovar as medidas, uma delas, o uso "generalizado" da água canalizada. Outra questão de saneamento recaía sobre a ventilação da rede subterrânea pelo sistema de "aplicação de calor", a ser implantado apenas quando a companhia cumprisse os compromissos assumidos no contrato. $\bigcirc$ tratamento das galerias principais era executado pela empresa com certa regularidade no período noturno (SÃO PAULO, 1885, p. 108). O presidente propos também que hovesse uma mudança no contrato de esgotos, com a eliminação da cláusula $4^{a}$ do contrato de 1877 , alteração que dependia da aprovação da Assembléia Provincial e da própria Companhia Cantareira, que ficaria sujeita a várias obrigações. Essa cláusula era a que obrigava a "Companhia a estabelecer na cidade uma canalização especial para o escoamento das águas pluviais" (SÃO PAULO, 1885, p. 108), mas o sistema de escoamento adotado pela companhia acabou sendo o misto, como afirma Bueno (1994). Para evitar a construção de uma canalização especial para pluviais, a companhia deveria cumprir as seguintes obrigações:

- Prolongamento do encanamento geral de esgotos e transferência da desembocadura do Tamanduateí para o Tietê.

- Fornecimento de água gratuito para o serviço de extinção de incêndio.
16. O uso do esgoto urbano para adubação na agricultura era um destino comum. Essa prática seria extinta entre os séculos XIX e XX, com as teorias de transmissão das doenças que condenariam essa utilização para a agricultura. Sobre o uso dos esgotos urbanos em agricultura, ver REID (1991). 
17. Flushing chambers eram equipamentos utilizados para realizar a limpeza dos esgotos. Segundo Brito (1943), o uso das descargas fluxíveis é recomendado quando "não se possa realizar a autolimpeza pela simples ação do deflúvio dos despejos" "Os benefícios das descargas fluxíveis não estão só no evitar a formação de depósitos, como também no libertar os condutos de um considerável volume de gases mefíticos, quer restringindo a sua formação, quer mesmo determinando a renovação do ar interior" (BRITO, 1943, p. 17,30 ). Como a maioria desses aparelhos eram estrangeiros e caros, Brito desenvolveu, em 1899, um modelo de tanque fluxível para ser utilizado no Brasil.
- Assentamento de válvulas de incêndio "quantas forem necessárias para ficarem elas, entre si, à distancia não maior de 200 metros, além de outras que serão, especialmente para seu uso, colocadas nos edifícios públicos".

- Fornecimento à seção de bombeiros de seis aparelhos stand-pipe.

- Fornecimento gratuito de água para mictórios públicos (SÃO PAULO, 1885, p. 108).

De um modo geral, a Cantareira cumpria o seu contrato com o governo provincial no tocante à distribuição de água para um perímetro que atingia alguns bairros da cidade (principalmente o centro), permanecendo pendências quanto à conclusão das obras de esgotos, obras complementares como a "cobertura por meio de aterro, dos coletores gerais, a construção de 'flushing chambers' ${ }^{17}$, nos pontos culminantes dos condutores principais e o estabelecimento de oito mictórios" (SÃO PAULO, 1885, p. 108). Como não estavam concluídas, houve uma prorrogação de três meses para entrega definitiva das obras, concedida pelo governo (Ato de 6 de maio de 1884). Por último, o relatório computa as reclamações dos usuários da companhia: de fevereiro a outubro de 1884 houve 263 reclamações pela falta de água, contra 130 solicitando a desobstrução dos esgotos.

No relatório datado de 18 de maio de 1885, José Luiz de Almeida Couto passa a presidência da Província para o vice-presidente Francisco Antonio de Souza Queiroz Filho, mas não menciona nada sobre a finalização das obras da Companhia Cantareira, detendo-se mais no andamento da Repartição de Obras Públicas, informações que voltam a aparecer, praticamente depois de dois anos, no relatório referente ao ano de 1886. Nesse documento, o barão de Parnaíba, presidente da Província, explica que até 31 de outubro a companhia havia recebido 3.418 pedidos de ligação de água, ficando assim "345 prédios com 401 penas e 3073 com hidrômetros". E ainda fornece outros dados:

Até a mesma data foram aferidos 3080 hidrômetros, dos quais 50 do sistema Siemens e 3030 do sistema Taylor. A medida diária de água fornecida a esta capital é de 2.500,00 litros, sendo 1.600.000 litros para o consumo particular, industrial, etc e 900.000 para a lavagem dos encanamentos e outros misteres da Companhia. É de 4450 o numero de prédios servidos por esgotos. Tem-se melhorado a ventilação dos mesmos, e a desinfecção dos ventiladores nas ruas continua a ser feita por meio de carvão vegetal (SÃO PAULO, 1887, p. 96).

Esse mesmo relatório informa que houve ainda a extensão da rede, que atingia agora o distrito compreendido entre as ruas João Theodoro e São Caetano. Quanto às reclamações dos consumidores sobre os serviços prestados, de novembro de 1885 a novembro de 1886, foram registradas 231 ocorrências. Sobre a condição da rede, relata que "todos os pontos culminantes dos condutores principais estão providos de flushing chambers, e os coletores gerais na várzea estão cobertos por aterro" (SÃO PAULO, 1887, p. 97). Mesmo com as melhorias 
e a afirmação do próprio governo que o "estado geral das obras é satisfatório", as obras ligadas à rede de esgotos não haviam sido concluídas até então, sendo a companhia, por esse motivo, multada pelo Ato de 21 de abril de 1886, mas logo anistiada pelo presidente da Província, com uma nova data para a conclusão das obras. Se por um lado o Estado perdoava as multas, a empresa, por sua vez, reclamava o pagamento de tributos no valor de 23:483\$800 "pois se julga prejudicada pelo Tesouro Provincial na sua liquidação de contas, constante do Relatório organizado em 3 de fevereiro do ano passado pela respectiva Comissão do Tesouro" (SÃO PAULO, 1887, p. 97).

A exposição de 1887, apresentada pelo presidente Rodrigues Alves, informa que 4.155 residências estavam utilizando a água fornecida pela Companhia Cantareira, 356 pelo sistema de pena e 3.799 pelo de hidrômetro. Talvez por ter percebido o aumento da população e conseqüentemente o crescimento da demanda por água encanada, a empresa construiu na Serra da Cantareira um novo reservatório de acumulação com as águas do Ribeirão Caratinga, que seriam utilizadas para a distribuição, mostrando assim que já no final da década de 1880 somente a canalização do Ribeirão da Pedra Branca $^{18}$ não seria suficiente para suprir a cidade de São Paulo, dando razão às vozes que se levantaram contra a utilização dos mananciais da serra, os presidentes da Província Antonio Candido da Rocha, Antonio da Costa Pinto Soares e José Fernandes da Costa Pereira Junior. Nesse ano, os reservatórios da Cantareira forneciam, por mês, uma média de 62.400,00 litros de água. No tocante aos esgotos, a rede estava ligada a 4.767 prédios "pagando 388 a taxa de $10 \$ 000$ anuais e 4.431 a de $36 \$ 000 "$ atingindo a companhia a quantidade de 528:645\$180 com as taxas arrecadadas. No serviço de saneamento dos esgotos, o mesmo vinha sendo feito com o carvão vegetal ${ }^{19}$, excetuando-se prédios situados no bairro de Campos Elíseos. Depois de diversas prorrogações, o governo provincial, pautando-se nas informações fornecidas pelo engenheiro fiscal, pela Câmara Municipal e pelo parecer do Tesouro Provincial, em "conformidade com os contratos de 9 de outubro de 1875 e atos da Presidência de 12 de dezembro de 1883 e 21 de abril de 1886", acabou por aceitar a conclusão das obras de abastecimento d'água e esgoto (SÃO PAULO, 1888, p. 105).

A escassez de informações contidas nos relatórios provinciais sobre as atividades da Companhia Cantareira pode ser explicada pelo fato de ser esse um momento em que a Província passou a se preocupar com outras questões importantes e decisivas para a sua economia, como, por exemplo, a definição de qual seria o melhor tipo de uso/ocupação do território paulista ${ }^{20}$, conhecimento que seria gerado pelos trabalhos da Comissão Geográfica e Geológica, criada em 1886. Os estudos daí advindos eram importantes para a expansão da cafeicultura e de outros setores agrícolas e industriais (COSTA, 2005). Mesmo com a atenção voltada para esse tema e para os melhoramentos do sistema viário da Província ${ }^{21}$, em 1889, o relatório de Pedro Vicente de Azevedo informa
18. Existe uma controvérsia entre os relatórios dos presidentes da Província e do engenheiro fiscal Manoel Ferreira Garcia Redondo.Enquanto os relatórios provinciais afirmavam que as águas do abastecimento vinham do Ribeirão Pedra Branca, Redondo diz que essas águas vinham dos mananciais do Toucinho, Guatemy e Barro Branco (REDONDO, 1889).

19. O carvão era utilizado para absorver e destruir o vapor orgânico (miasmas) provenientes dos esgotos, para que não invadissem as residências (LATHAM, 1878), em concordâncias com as teorias de transmissão das doenças da época.

20. Nossas pesquisas apontam que a preocupação com o melhor conhecimento do solo paulista estava presente no debate político da Província desde 1880, quando é apresentado ao governo a Carta corográfica da Província de São Paulo, uma proposta realizada pelos engenheiros Antonio Francisco de Paula Souza, Adolpho Augusto Pinto e João Pinto Gonçalves.

21. Em 1881 o então presidente da Província, Laurindo Abelardo de Brito, estabeleceu uma comissão para estudar a viação do território paulista, atendendo a um aviso do governo imperial.A correspondência de Antonio Francisco de Paula Souza aponta que, nessa comissão, além do referido engenheiro, estava presente também Antonio Cândido Rodrigues, Eugenio de Lacerda Franco, Carlos Herman Ludolf Prohe, Domingos Corrêa de Moraes. 
que os serviços de distribuição de água tinham sido feitos com regularidade atingindo o número de 4.887 prédios (4.505 em sistema de hidrômetro e 382 no de pena). Mas, anunciando também a precariedade financeira da empresa, o presidente justificava a ausência de rede de esgotos "nas ruas ultimamente abertas e nas casas há pouco construídas", sendo que estavam ligados à rede 5.113 prédios, "dos quais 4766 são de valor locativo superior a $14 \$ 000$, e 347 de valor inferior a esta quantia", valores importantes para que a Província repassasse parte de sua arrecadação sobre a taxa de esgotos para a companhia, que havia sido de 683:605\$980. Até outubro de 1887 foram realizadas 405 reclamações "sobre entupimentos na canalização das matérias fecais, sendo todas atendidas" (SÃO PAULO, 1889a, p. 90). Por último, o Relatório de 1889 informa que para liquidar as contas do Tesouro Provincial sobre o serviço de esgotos referente ao período de janeiro de 1883 a 30 de junho de 1885, que ainda não havia sido pago, o próprio presidente havia aberto um crédito especial para o pagamento da companhia no valor de 23:483\$500.

O espaço de tempo compreendido entre 1888 e 1889 foi um período de turbulências dentro do cenário político brasileiro, com a abolição declarada e o movimento republicano, gerando assim um quadro de adaptação ao novo regime e de construção de um novo aparelho de Estado. Além da instabilidade política, piorou muito o estado sanitário da ex-Província ou com a chegada dos surtos epidêmicos de varíola e de febre amarela, por volta de 1888. Tanto era verdade que a Fala do barão de Jaguara, de maio de 1889, voltava-se com exclusividade para o estado sanitário de cidades como Campinas e Santos, atingidas pela febre amarela, logo se transformando num quadro de epidemia, "causando forte abalo no comércio, na lavoura e nas indústrias da Província, relacionadas diretamente com ambos aqueles empórios importantíssimos". Nessa mesma Fala, o presidente aponta como um dos responsáveis pelo surgimento da febre a água fornecida para essas cidades: "e todos verificamos pessoalmente os estragos da epidemia, cuja causa primordial ficou provada ser a péssima qualidade da água, viciada pelas infiltrações e pela falta de esgotos" (SÃO PAULO, 1889b, p.89). Foi a partir desse momento que ganha importância a necessidade da construção das redes de infra-estrutura urbana para as cidades do interior e da própria capital. Enquanto discutia-se a concepção de redes de águas e esgotos para as outras cidades do interior, na capital, o governador Jorge Tibiriçá (1890) anunciava que haviam sido aprovados "os preços para as obras extraordinárias" e que a Cantareira ofereceria melhoramentos tocantes principalmente à rede de esgotos. Ao todo, eram 35 itens, entre latrinas, válvulas, assentos de madeira, cisternas de ferro galvanizado, ventiladores, canos de chumbo, caixas de gordura e mictórios.

Observa-se que a companhia passou a oferecer uma gama maior de materiais para encanamentos, novos componentes de manutenção e ainda apresentava acessórios como louças sanitárias e assentos, suplementos que vinham cada vez mais conquistando espaço dentro da vida urbana moderna no 
mundo (CSERGO, 1988). Mesmo com o oferecimento de novos equipamentos não se estava atacando o problema principal, apontado pelo engenheiro fiscal Redondo, que era a extensão das redes de águas e esgotos a todos os subúrbios da cidade (REDONDO, 1889). Outro problema que começava a se delinear era o da pouca água fornecida pelos mananciais, incapazes de garantir o abastecimento para a cidade. Concomitantemente aos problemas da Companhia Cantareira, iniciou-se um processo de reestruturação do aparelho de Estado, durante o governo provisório da República ( 1889 a 1892), com a sua adaptação para as necessidades infra-estruturais do período. Era o Estado que chamava para si a tarefa de produção da infra-estrutura.

Outras importantes modificações foram feitas na administração do governador Cerqueira César que pelo Decreto n. 28 de 1ำ de março de 1892 organizou as Secretarias da Justiça, do Interior e Agricultura, Comércio e Obras Públicas, sendo essas duas últimas que dirigiam respectivamente as Comissões Sanitária e de Saneamento, responsáveis pela criação de uma série de equipamentos e melhoramentos urbanos na capital e no interior. Pelo Decreto n. 29 de $1^{\circ}$ de março de 1892 foi criada também a Secretaria de Estado da Fazenda, reorganizando assim o Tesouro do Estado, responsável pela arrecadação de impostos e pelo repasse de verbas para a Companhia Cantareira ISÃO PAULO, 1913). Organizadas as principais secretarias e postas em funcionamento, logo - governador voltou-se para o problema das epidemias e as suas conseqüências para o desenvolvimento econômico do Estado:

As epidemias que assolam o principal dos nossos portos, não só perturbam gravemente o mecanismo econômico do Estado e ameaçam de sérias dificuldades a sua comunicação comercial com o exterior, mas expõem também todo o território paulista a uma invasão da febre amarela, como uma cruel experiência nos tem demonstrado (MENSAGEM, 1892, p. 15).

No governo Cerqueira César, foi evidente a preocupação com o estado sanitário de São Paulo, chamando-se inclusive o renomado higienista Estevan Fuertes para estudar uma solução para a cidade portuária de Santos. Entre os problemas mais graves de saneamento de seu governo, estava também a resolução do "problema urgentíssimo do abastecimento de água e canalização de esgotos da Capital, que não tem sido levado a efeito pela Companhia contratante, e não poderá ser sem o concurso do estado, auxiliando-a, ou anulando o seu contrato e chamando a si a execução dos serviços" (MENSAGEM, 1892, p. 15), (grifos nossos). Sua fala deixa evidente que a Companhia Cantareira atuava de forma irregular, pois não estendeu os seus serviços de águas e esgotos para os novos distritos da cidade de São Paulo. A leitura dos relatórios da Presidência da Província permite uma forma parcial de análise da atuação da Companhia Cantareira. Um contraponto para essa questão foi conseguido com a leitura dos relatórios da Secretaria dos Negócios da Agricultura e em pareceres dos engenheiros fiscais sobre a atuação da companhia, discussão essa que ocorria desde 1890. 
A incorporação da Companhia Cantareira pelo Estado, 1889 -1892

Se pelos relatórios provinciais é pouco evidente que existia um descontentamento da população e do governo com a Companhia Cantareira, por outro lado, a leitura dos relatórios do engenheiro fiscal Redondo, da Superintendência de Obras Públicas e da Secretaria dos Negócios da Agricultura, entre 1890 e 1892, mostra como determinados membros do governo provisório estavam discutindo e colocando em xeque o desempenho dessa companhia e dos seus serviços prestados para a cidade de São Paulo. $O$ debate em torno da renovação do contrato ou a encampação da companhia iniciou-se em 1889, com as denúncias feitas pelo então engenheiro fiscal Manoel Ferreira Garcia Redondo. Na esfera pública, a atuação da empresa passou a ser revisada com a publicação da Lei n. 195 de 5 de junho de 1889, que autorizava o governo a rever os contratos anteriores e "a emprestar à Companhia Cantareira e Esgotos mil e quinhentos contos de reis, ou a encampar o serviço de água e esgotos" (REDONDO, 1889, p. 5). Para fornecer dados precisos sobre o desempenho da empresa, o presidente da Província, general Couto de Magalhães, convocou o engenheiro fiscal da companhia para apresentar dados que permitissem ao governo averiguar, de fato, a real situação desses serviços em São Paulo. Sobre o abastecimento, disse que a cidade recebia 1.849.500 litros diários de água da empresa, o que o leva a denunciar o precário estado sanitário da cidade:

[...] sendo a população de S. Paulo de cerca de 60.000 almas, segue-se que a média do consumo por habitante não excede de 30 litros diários, o que leva a crer que uma boa parte da população se abastece de outra água que não a da Cantareira. De fato, a população que habita fora do perímetro servido pela Companhia não se abastece da água da Cantareira e mesmo uma parte da que vive dentro desse perímetro consome outra água, como prova o fato de existirem 5702 prédios servidos de esgotos e apenas 5503 abastecidos de água (REDONDO, 1889, p. 8-9).

Na conclusão de seu parecer, o engenheiro fiscal não tomou uma posição clara quanto à encampação dos serviços da Cantareira, pelo contrário, apontou quais seriam as medidas necessárias para viabilizar o sistema de saneamento básico de São Paulo. A primeira dessas medidas seria o aumento do perímetro dos serviços, a "obrigatoriedade da água para a lavagem das bacias na quantidade de 150 litros diários cada uma", seguidas das seguintes obras: aquisição de novos mananciais que dobrem a produção de água da Cantareira; construção de um novo reservatório de distribuição com capacidade entre 10 a 12 milhões de litros, assentamento de um novo cano mestre com o dobro ou triplo da capacidade do que era utilizado para ligar o reservatório de acumulação ao de distribuição (REDONDO, 1889, p. 30 -3 1). Para os esgotos, Redondo sugeriu as seguintes modificações: levar a desembocadura do esgoto para dois quilômetros abaixo do ligado à Ponte Grande; construir "chaminés de chamada alimentadas à gás" para melhorar a ventilação da rede; tornar obrigatório o uso de tubos de aspiração para os water-closet, com saída acima 
dos telhados das habitações; conservar o despejo in natura ou se, em caso de enchentes e não ocorrendo o escoamento contínuo, evitar que as águas do rio se tornassem "infeccionadas", sendo o caso de despejar o esgoto em reservatórios, desinfetando as águas ou as utilizando na irrigação de terrenos. Uma última ressalva do engenheiro, a seu ver, urgente, era o abastecimento de água nos "prédios existentes dentro do atual perímetro da Companhia e que estão servidos de esgotos, sem no entretanto terem água para os lavar" (REDONDO, 1889, p. 31-32).

Para corrigir defeitos contratuais desse tipo, a Assembléia Legislativa paulista decretou a Lei n. 195 de 5 de junho de 1889, justamente para

[...] rever os contratos da Companhia e modificá-los no sentido de serem igualados e alargados os perímetros para o serviço de água e esgotos, de serem igualados os prazos dos contratos para o gozo dos privilégios dos dois serviços; de ser estabelecida a obrigatoriedade da água para a lavagem das bacias [...]; e finalmente, de poder o Presidente da Província emprestar à Companhia até 1500 contos, ficando, outrossim, o Presidente autorizado também a encampar os serviços de água e esgotos quando julgasse conveniente ao interesse público (REDONDO, 1889, p. 4).

Assim, em 1890, um quarto contrato estava sendo elaborado entre a Cantareira e o governo estadual, por meio da pessoa de Jorge Tibiriçá, secretário da Agricultura. Enquanto corriam as negociações, ocorreram mudanças no governo, como a extinção do cargo de engenheiro fiscal em 15 de janeiro de 1890, passando a responsabilidade da fiscalização de todas essas empresas prestadoras de serviços públicos no Estado lágua e esgotos, iluminação pública, gás, viação, etc.) para a Superintendência de Obras Públicas, criada em 1889. Reportando-se para a superintendência, a Companhia Cantareira enviou ofício pedindo isenção de impostos aduaneiros para a importação de material para a extensão e conclusão das obras a seu cargo. Em resposta a esse ofício, o então diretor da superintendência, o engenheiro Antonio Francisco de Paula Souza, explicou que essa questão era analisada pela $3^{\underline{a}}$ Seção da repartição ${ }^{22}$, cujos estudos resultariam na "elaboração das bases para o novo contrato" com a companhia, frisando que estava de perfeito acordo com o que o chefe da secção considerou e alterou, mas advertiu: "só o faço em virtude de cumprimento de ordens; pois que penso que serviços da natureza dos que se trata devem sempre [estar] a cargo dos poderes municipais e serem executados por eles a fim de estarem completamente livres das vicissitudes inevitáveis de uma exploração mercantil", ressaltando ainda que a seu ver o contrato não seria renovado e a companhia seria encampada e seus serviços entregues

a uma comissão municipal, que oportunamente seria substituida pela Comissão de Águas e Esgotos da capital regularmente eleita pelo povo ou nomeada pela municipalidade regularmente constituída. Esta comissão dirigiria o serviço de águas e esgotos com completa independência, nomearia seus Engenheiros e seus empregados fiscais e colaboradores e prosseguiria neste serviço sem outro incentivo senão o interesse municipal ao qual teria de prestar contas semestrais. Livre assim de interesses mercantis este serviço não só deverá ser
22. A Superintendência de Obras Públicas era composta de quatro secções: $1^{\text {a }}$ responsável pela construção, melhoramento e conservação de pontes e estradas; $2^{\mathrm{a}}$ pelas construções civis; $3^{\text {a }}$ pela fiscalização de empresas, demarcação e divisão de terras públicas e inspeção de colônias e a $4^{\text {a }}$ composta pela Comissão Geográfica e Geológica (SÃO PAULO, 1890, p. 17-18; COSTA, 2003) 
melhor executado como principalmente ter muito mais atenção as diversas questões higiênicas de alta importância para a salubridade desta capital (SUPERINTENDÊNCIA DE OBRAS, 1890, p. 1-31.

Nota-se que a opinião do diretor da superintendência já tinha sido expressa em relatório dirigido ao secretário da Agricultura, quando expos abertamente que esse tipo de serviço deveria ser municipal, justificando que uma empresa de águas e esgotos exigia "conhecimentos especiais para projetar e realizar as obras necessárias", de "natureza uniforme e constante que pode muito bem ser dirigido por pessoas que não tenham imediato interesse nele" e "conviria mais aos interesses munícipes que ele fosse dirigido por funcionários municipais. Infelizmente, entre nós, tem-se querido fazer desse serviço essencialmente de higiene pública de máxima importância uma exploração mercantil". Explicou que nos contratos anteriores fechados com a companhia todas as cláusulas permitiam a essa a possibilidade de "vexar quando quiser o público", o que a levou a enriquecer e a estagnar, "sem premunir-se com os meios necessários para atender ao natural aumento de consumo d'água". Indicou ainda que a capacidade de fornecimento era pouca por causa dos encanamentos com dimensões que não permitiam vazão maior de 3.500 metros cúbicos, com reservatório de capacidade de três $\mathrm{mil} \mathrm{m}^{3}$, fornecendo a quantidade de cem litros por habitante, insuficiente, segundo Paula Souza, para uma população de 30 mil almas. Criticando duramente a companhia, chamando o contrato de 7 de abril de 1877 de "omisso", disse: "parece que os intuitos da Companhia limitam-se à realização de boas operações financeiras, sem se preocupar um só momento das graves conseqüências que as medidas arbitrárias e vexatórias que tem estabelecido hão de inevitavelmente trazer" (SUPERINTENDÊNCIA DE OBRAS, 1890, p. 205-206).

Suas críticas não cessaram no abastecimento, pois o engenheiro atacou também as irregularidades do serviço de esgotos, advertindo que essa rede era feita com materiais porosos, impróprios para esse tipo de escoamento. Paula Souza disse que quando começou a interar-se da situação dos esgotos, enfrentou resistência por parte da gerência da companhia que não atendia aos pedidos nem executava as portarias expedidas pela superintendência. $\mathrm{Na}$ conclusão desse assunto sobre os serviços da companhia, voltou a enfatizar que

o serviço de abastecimento d'água e esgotos nunca deve ser executado e explorado por companhias, cujos fins não podem deixar de ser mercantis em primeiro lugar, pondo sempre as questões de salubridade e higiene em segundo plano, mas sim por comissões municipais, designadas pelas Intendências, ou melhor, eleitas pelo povo para a formação das quais os munícipes deveriam escolher seus melhores concidadãos (SUPERINTENDÊNCIA DE OBRAS, 1890, p. 207).

Pelo conjunto de suas críticas, expressas em relatório e ofícios, podese concluir que o engenheiro Paula Souza era favorável à encampação da companhia e que esses serviços deveriam ser gerenciados pelo governo.

Mesmo com o posicionamento contrário de diretores como Paula 
Souza, um novo contrato com a Companhia Cantareira foi lavrado em 29 de novembro de 1890. A partir dessa data ficou evidente que as ações da companhia ocorriam com certa morosidade, segundo o diretor da Superintendência de Obras Públicas, José Pereira Rebouças:

- Em 14 de janeiro de 1891 "foi deferida a petição da Companhia pedindo restituição da quantia de 3:000\$000, que foram deduzidos do pagamento feito pela taxa de esgotos do semestre findo a 30 de junho de 1890 como vencimento do engenheiro fiscal da mesma companhia".

- Acontecera a aprovação do governo para a utilização das águas dos ribeirões Guayanna e Aricanduva "a fim de serem aproveitadas no abastecimento desta capital" e a apresentação de estudos para - abastecimento da "zona baixa da cidade com águas do Aricanduva e aos serviços de esgotos dos bairros da Penha, Bom Retiro, Campos Elíseos e Santa Cecília", planos esses considerados deficientes pelo governo, o que fez o mesmo denunciar a empresa por "falta de cumprimento da cláusula $1^{\underline{a}}$ do contrato de 29 de novembro", o que resultou para a empresa ainda uma multa de 2:000\$000. O despacho de 11 de abril oferecia à empresa o prazo de quatro meses, contados a partir de 15 de abril, para a entrega dos planos definitivos para o abastecimento e a rede de esgotos da cidade, resolvendo também "não autorizar a execução de quaisquer trabalhos, antes que fosse exibido o projeto definitivo de canalização d'água e da rede de esgotos relativos aos bairros da Penha, Bom Retiro, Campos Elíseos e Santa Cecília".

- Ocorrera em caráter provisório, para solucionar a falta de água que atingia parte da cidade desde setembro de 1890, a permissão do governo para que fossem feitas obras de canalização do Aricanduva para abastecer a Penha e o Brás, mas alegando falta de material, a companhia requereu junto ao governo realizar a canalização do Ipiranga "destinando-o ao abastecimento da zona baixa desta capital", obra que ficou pronta parcialmente em novembro de 1891 , depois de três "sucessivas prorrogações", e fornecendo água para uma "pequena zona baixa da capital", alegando que a falta de material "inibiu-a de levar os encanamentos mais a montante do ribeirão". Mesmo parcial, o serviço permitiu que a companhia concentrasse o abastecimento da "Serra à zona alta da capital e sanar algum tanto as faltas que fortemente ali se davam".

- Realizou-se uma listagem dos prédios ligados à rede de esgotos, para o fisco, e em 18 de setembro de 1891 "concluíram-se as contas do pagamento do serviço de esgotos do semestre de janeiro a junho de 1891, na importância de 101:962\$580, correspondente a 5779 prédios da taxa de $36 \$ 000$ e 111 prédios classificados para a taxa de 10\$000, com as deduções estabelecidas". 
23. Esses empreiteiros do assim chamado Escritório da Construção das Obras de Abastecimento d'Água e Esgotos de São Paulo eram Antonio Manuel Bueno de Andrada (engenheiro), Luiz Felippe Gonzaga de Campos e Vicente Huet Bacellar Pinto Guedes (SÃO PAULO, 1893b, p. 85)
- Como a companhia não conseguira entregar os novos estudos exigidos pelo governo no despacho de 11 de abril, pediu mais um mês de prazo, sendo esse negado pelo governo. A companhia entregou então os estudos, que são analisados pela Superintendência de Obras Públicas e considerados incompletos, mas mesmo assim deveriam ser as obras iniciadas no prazo de três meses. (REBOUÇAS, 1892, p. 86-90).

Rebouças concluiu que o abastecimento da capital não deveria ter mais atrasos, porém advertiu que o problema só poderia ser resolvido "em prazo muito longo, dentro do qual será difícil evitar-se que seja sacrificada por alguma calamidade a população desta capital, com esgotos servidos com água já deficiente para os usos ordinários da vida" (REBOUÇAS, 1892, p. 40).

No relatório publicado pela Secretaria da Agricultura, referente ao ano de 1892, o então secretário Jorge Tibiriçá iniciou sua fala sobre as "águas e esgotos" de São Paulo apontando para um problema que se arrastava há muito tempo, e que a companhia, pelo contrato de 29 de novembro de 1890, tinha "acanhadamente" começado obras para o aumento do suprimento de água e esgotos para os bairros não servidos com esses benefícios. Para contornar o problema, o governo lançou o Decreto n. 69 de 28 de maio de 1892, que o permitia fazer um outro contrato provisório com a Companhia Cantareira "para execução dos serviços mais urgentes". O contrato provisório de 17 de junho possuía as seguintes metas:

1 o prolongamento da canalização do lpiranga no intuito de dar maior pressão à rede de encanamentos servida por esse manancial; 2ำ a canalização do córrego Cassununga para o atual reservatório de acumulação na Serra da Cantareira no intuito de evitar que se reproduzisse o fato, que já tinha se dado, de ser a quantidade de água recebida no reservatório inferior à quantidade que o encanamento mestre pode trazer à cidade; $3^{\circ}$ construção da galeria principal de esgotos de Santa Cecília, Campos Elíseos e Bom Retiro (RELATÓRIO SECRETARIA DA AGRICULTURA, 1893a, p. 7).

As metas acima propostas eram, aos olhos do governo e nessa altura dos acontecimentos, algo impossível de ser cumprido pela companhia, fazendo com que o Congresso do Estado, pela Lei n. 62, autorizasse "o poder executivo a rescindir o contrato de 29 de novembro de 1890, encampar a Companhia Cantareira e Esgotos e mandar executar as obras de abastecimento de águas e desenvolvimento da rede de esgotos". Ao que tudo indica, parece que houve resistência da diretoria em aceitar a encampação logo de início, fato que seria consumado apenas no mês seguinte quando os empreiteiros ${ }^{23}$ das obras da companhia em ofício para a diretoria "declararam não prosseguirem nas obras desde que passassem a cargo do Governo", fato que levou o presidente da empresa a dirigir-se ao secretário de Agricultura "pedindo que mandasse tomar conta das obras e fazer a medição do serviço executado" ISÃO PAULO, 1893, p. 7). Além de encampar os serviços e iniciar o desenvolvimento das novas obras, a Lei n. 52 autorizava a criar "repartição especial para sua direção, a 
lançar mão dos saldos do Tesouro, ou a efetuar as operações de crédito precisas para os pagamentos". E também "dispõe ainda sobre a transferência dos serviços à municipalidade da capital, depois de concluídos", conforme já havia preconizado o engenheiro Paula Souza quando diretor da superintendência (RELATÓRIO ANUAL SECRETARIA DOS NEGOCIOS, 1895, p. 11 ). Assim, a Superintendência de Obras Públicas acaba por assumir em definitivo as obras da companhia.

A produção estatal do saneamento: a Repartição Técnica de Águas e Esgotos

Anexa à Secretaria da Agricultura, a Superintendência de Obras Públicas agregava uma série de atribuições. Em 1891, o relatório dessa secretaria apontava, segundo Bernardini (2003), a necessidade de se fazer uma reorganização na superintendência, para que fosse possível aplicar um montante de recursos vindos dos impostos gerados pelas exportações cafeeiras. Essa reorganização permitiu ao órgão ganhar "contornos mais precisos quanto à sua competência" e duas seções, sendo a primeira de obras civis e a segunda os serviços de fiscalização das empresas prestadoras de serviços. Havia uma ramificação especial dentro da superintendência, que era a Repartição Técnica de Águas e Esgotos (RTAE), criada pelo Decreto n. 154 de 8 de fevereiro de 1893. Outro destaque para o saneamento paulista foi a criação da Comissão de Saneamento, pelo Decreto n. 56-A de 30 de abril de 1892, órgão responsável pelas obras de saneamento na capital e em diversas cidades do interior paulista (BERNARDINI, 2003, p. 61). Antes da criação da RTAE, conforme já foi dito, as obras deixadas pela Companhia Cantareira foram retomadas pela própria superintendência.

De caráter emergencial, essas obras logo após a encampação, em 1892, foram as seguintes:

- Galeria principal de esgotos de Santa Cecília.

- Canalização do Cassununga para o reservatório (para abastecer a parte alta da cidade).

- Revisão dos estudos de captação do Ipiranga (para abastecer a parte baixa da cidade), locação desse serviço e da abertura da estrada ao longo da canalização a ser efetuada.

- Assentamento de 2.786 metros de canos da Liberdade até o Morro Vermelho, para levar a rede até as ruas Glicério, Lavapés e Tamandaré.

- Criação de uma secção especial dentro da superintendência para gerenciar as obras de água e esgotos, sob a direção do engenheiro Carlos Ribeiro de Moura Escobar, o embrião do que viria a ser a RTAE. 
- Nomeação dos engenheiros Adrieu Milos e João Baptista Gautier (auxiliar) para rever e completar os estudos da rede de esgotos.

- Autorização para a construção do tramway com destino a Serra da Cantareira, para transporte de material até o alto da serra.

Já o outro ramo da Secretaria da Agricultura, a Comissão de Saneamento, também teve ações paralelas para reverter a situação deixada pela Companhia Cantareira. Em 1892 a comissão atuava no Bom Retiro, "bairro [...] desprovido de limpeza, drenagem, esgotos e água", na construção de galerias de drenagem e águas pluviais, na implantação do tramway executando reconhecimento e estudos da linha entre o Pari e a Serra da Cantareira e no levantamento de planta dos bairros do Pari, Brás e Imigração, além da execução de limpeza, remoção de lixo, abertura de valas e valetas em determinados locais da cidade (COMISSÃO DE SANEAMENTO, 1893, p. 18).

A organização da Repartição Técnica de Águas e Esgotos ocorreu em 8 de fevereiro de 1893 e estava dividida em uma seção geral, uma divisão central e em seis divisões auxiliares. Segundo o Relatório da Superintendência de 1895, repartição que a RTAE estava vinculada, iniciou-se oficialmente o gerenciamento das redes de águas e esgotos de São Paulo nos últimos meses de 1893. Até 1894, as principais obras no setor de abastecimento da capital concentraram-se no "assentamento de novas canalizações pelo melhoramento com tubos de maiores diâmetros de grande parte da rede estabelecida pela companhia Cantareira", dessa forma "conseguiu-se sem demora regularizar-se o abastecimento d'água e aceitar-se, realizando francamente, os pedidos de ligações para casas particulares e para outros serviços congêneres". A regularidade na distribuição nos bairros altos da cidade (reservatório Consolação) foi acentuada nos últimos meses de 1894 quando efetuou-se por completo a canalização das águas dos ribeirões Cassununga, Cachoeira, Campo Redondo e Engordador, ficando os trabalhos da parte alta muito adiantados, faltando-se concluir a rede de distribuição como estabelecimento de canalizações de menor diâmetro (Figura 4). Na parte baixa da cidade, no bairro do Brás, também havia sido regularizado o fornecimento com a conclusão da canalização do Ipiranga.

Para a perfeita distribuição de água na cidade, a RTAE realizou a seguinte divisão em zonas:

1ำ Zona Central e Comercial da cidade, bairros do Bom Retiro, Luz, Santa Efigênia, Santa Cecília e Campos Elíseos servidos pela canalização de 0,60m.

$2^{a}$ Zona entre proximidades do Largo da Sé, bairros da Glória, Bela Vista, Vila Buarque e rua Fagundes (cota 775) servidos pelo reservatório da Consolação, que recebe o antigo cano de $0,30 \mathrm{~m}$ e as sobras do reservatório da Liberdade.

$3^{a}$ Zona alta da cidade, servida pelo reservatório da Liberdade e diretamente pelo encanamento adutor dos córregos Cassununga, Cachoeira, Campo Redondo e Engordador. 


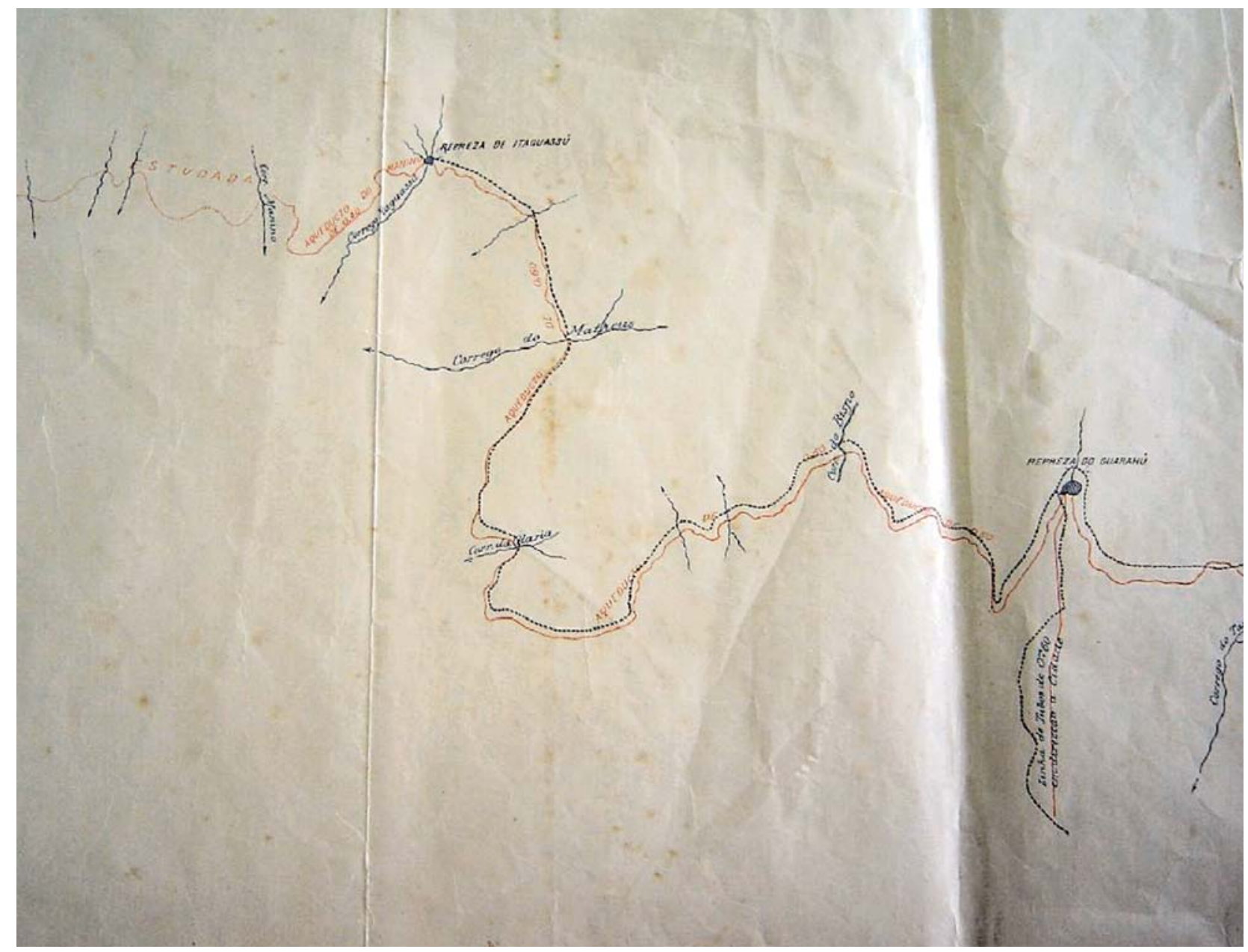

Figura 4 - Ao encampar os serviços da Companhia Cantareira, um dos primeiros trabalhos da Repartição Técnica de Águas e Esgotos foi o mapeamento da zona hidrográfica da Serra da Cantareira e de outros ribeirões e rios próximos da cidade em condições de complementar o abastecimento precário efetuado pela companhia. Detalhe da Planta Geral da Zona Hidrográfica da Serra da Cantareira com a Indicação dos Serviços feitos até 31 de Dezembro de 1894. Acervo do Arquivo do Estado de São Paulo.

4ª Bairro do Brás, servido pela canalização do lpiranga, com a próxima terminação dos trabalhos de captação dos mananciais à direita. IRELATÓRIO DA SUPERINTENDÉNCIA DE OBRAS PÚBLICAS, 1895, p. 209).

Com todo esse aparato para a distribuição, em 1895, a cidade dispunha de 27 milhões de litros para consumo diário.

Novas obras de captação em andamento, segundo esse mesmo relatório, deveriam aumentar na canalização de $0,60 \mathrm{~m}$ para 15 milhões de litros, mas o objetivo era de se chegar aos 21 milhões para completar sua capacidade, precisando inclusive aumentar a mesma no reservatório da Consolação, que não apresentava mais "seguras condições de estabilidade e 
segurança". Um dado a ser destacado no abastecimento é a utilização do hidrômetro como instrumento de medição para o consumo de água nas residências, sendo o uso desse aparelho consagrado inclusive no Código Sanitário estadual (RELATÓRIO DA SUPERINTENDÊNCIA, 1895, p. 209-2 10). Finalmente, destacamos que foi a RTAE a responsável pela demolição dos últimos chafarizes, locais de distribuição pública de água, como uma forma de obrigar a compra do produto dessa repartição pública, consolidando assim a água como mercadoria (VILLAR, 2003).

Sobre a rede de esgotos, informa o diretor da superintendência, que a situação teve bom andamento nos bairros da Consolação, Santa Cecília, Campos Elíseos, Bom Retiro, Luz, Liberdade e Bela Vista, "estando nos primeiros terminados os serviços de ligação às casas". Porém, o problema maior concentrava-se no Brás, onde o serviço era "dispendioso e dificultoso", sendo preciso "iniciar e atacar em vários pontos a construção do coletor principal e [...] os secundários". Sem uma previsão do início das obras, já que com a verba reduzida do orçamento não seria possível realizar tais melhoramentos, o diretor ressalta a necessidade de um pedido de aumento de verba ao congresso. (RELATÓRIO DA SUPERINTENDÊNCIA, 1895, p. $210-211$ ).

Pode-se dizer que a Repartição Técnica de Águas e Esgotos, organizada pelos engenheiros Antonio Francisco de Paula Souza e Theodoro Sampaio (COSTA, 2003, p. 219 ), buscava um diferencial

Visando contrapor-se à administração anterior, a RAE buscou realizar uma quantidade significativa de obras de ampliação (captação e distribuição) das redes de água e esgoto e, desta forma, acompanhar o crescimento espantoso pelo qual São Paulo vinha passando (COSTA, 2003, p. 66-67).

A encampação da Companhia Cantareira apresentou, em um primeiro momento, despesas para o Estado:

A despesa foi da importância de 30.884:490\$303, sendo a ordinária de 18.559:061 \$139, e a extraordinária, por créditos especiais e amortização da dívida, de 12.325:429\$164. Esta parte da despesa foi absorvida com a encampação dos bens da Companhia Cantareira e Esgotos de São Paulo, feita de acordo com a Lei n. 62, de 17 de Agosto de 1892, com o desenvolvimento dado aos serviços a cargo dessa empresa, com a organização de assistência pública, e outros, em execução de disposições legislativas (SÃO PAULO, 1893a), (grifo nosso).

Quando o Estado passa a promover a produção do saneamento (uma produção que necessita de grande soma de dinheiro), são visíveis as melhoras conquistadas para o abastecimento como para a própria condição sanitária da cidade:

É notável a presteza com que se executaram custosas e fundamentais obras, como as que, depois da encampação da companhia Cantareira e Esgotos, se realizaram na Serra da Cantareira e na cidade, para o abastecimento de água, assim como a extensa e profunda galeria de drenagem em vários pontos, medida indicada como remédio radical para a 
extinção de focos perniciosos que ultimamente transformavam em zonas perigosas as que agora apresentam reabilitadas, graças a essas obras e à intervenção das medidas ordinárias de higiene (SÃO PAULO, $1916 d$, p. 32).

Se no relatório de 1894 os trabalhos da RTAE tiveram considerável avanço, em 1895 e 1896, os relatórios mostram que a repartição havia recuperado o atraso causado pela Companhia Cantareira:

Tendo, em obediência a acertada resolução vossa, encampado as obras da Companhia Cantareira, deficientíssimas para satisfazer as necessidades da crescente população, quanto ao abastecimento de água e aos esgotos, conseguiu a ação do Governo, secundada pela competência, energia e dedicação de ilustres profissionais, ampliá-las de tal modo, que o fornecimento do indispensável líquido elevou-se de 3.500.000 litros diários a 3 1.200.000, devendo ainda mais subir este algarismo. Foram adquiridas para o Estado todas as nascentes dos mananciais e as matas circundantes; construíram-se sólidas represas, aquedutos, monumentais reservatórios, estabeleceram-se mais duas linhas de encanamentos de ferro da Serra para a cidade, sendo uma de 0.60 de diâmetro, além da existente, levando água para todos os pontos e com abundância, ainda aos mais altos. Desenvolveu-se a rede de esgotos, de modo a servir a toda a área povoada, chegando as obras até aos extremos da cidade, subordinadas a um plano normal. (SÃO PAULO, 1916f, p. 70), (grifo nosso).

As últimas mudanças significativas na RTAE ocorreriam no ano de 1898, quando é desvinculada da Superintendência de Obras Públicas, passando a ser dirigida pelo engenheiro sanitarista Theodoro Sampaio, por indicação do então secretário Estadual da Agricultura, Comércio e Obras Públicas e também engenheiro Antonio Francisco de Paula Souza. Sem dúvida, a produção do saneamento torna-se mais efetiva e presente a partir do momento em que o Estado toma para si a produção dessa infra-estrutura.

Considerações finais

Sobre a produção do saneamento em São Paulo

Um novo sistema de abastecimento de água para a cidade de São Paulo era uma reivindicação antiga da população da cidade, queixosa quanto à pouca quantidade do líquido fornecido para consumo. Era um problema a ser resolvido pelo Estado que, de início, passou a promover a rede de infraestrutura chamando os interessados para que apresentassem propostas ao seu desenvolvimento. Muitas propostas foram analisadas, mas nenhuma contemplou as expectativas dos governantes, que acabaram contratando um engenheiro inglês para realizar um estudo que solucionasse de uma vez o problema da falta de água na cidade. O estudo realizado por Brunless, segundo mencionamos neste trabalho, foi feito sem muito conhecimento acerca da capacidade dos mananciais da Serra da Cantareira, local afastado da cidade que apresentava uma excelente qualidade de água. Acertado o projeto, o próximo passo do 
24. Essa afirmação foi defendida pelo prof. dr. Carlos Roberto Monteiro de Andrade (EESC/USP), durante reunião do grupo de pesquisa Habitação e Urbanismo, no primeiro semestre de 2005.
Estado promotor foi chamar empresários interessados em produzir tal infraestrutura, processo que demandou tempo, já que a obra necessitava de avultada soma de capitais para sua execução, o que a inviabilizava para apenas um empresário, sendo preciso assim o agrupamento de vários acionistas para comporem a Companhia Cantareira \& Esgotos, entre 1875 e 1877.

A Companhia Cantareira não teve, conforme vimos, o desempenho esperado de uma empresa prestadora de serviços públicos, pois suas obras não eram entregues no prazo estipulado pelos contratos, prorrogando por alguns meses a finalização das redes. Por outro lado, não podemos deixar de destacar que os trabalhos da companhia trouxeram benefícios para a comunidade, sendo inclusive as obras executadas consideradas de alta qualidade, trazendo para a cidade novos costumes e hábitos domiciliares e urbanos. Se por um lado houve melhorias, é relevante mencionarmos que a mesma companhia foi ressarcida tanto pelo próprio governo estadual, com as taxas sobre os esgotos, como também pela população que passava a pagar com o fornecimento d'água um dinheiro que rumava para os acionistas da empresa, geralmente indivíduos já envolvidos em outras empresas de prestação de serviços. Porém, a empresa não acompanhou o acelerado ritmo de crescimento que a cidade de São Paulo atravessou nas últimas décadas do século XIX, sendo necessária a sua encampação pelo Estado. A estatização da companhia ocorreu em um momento significativo da constituição do Estado republicano, época em que se formaram as suas bases de atuação nos diversos setores que competiam à administração pública. Outro marco significativo é a participação dos engenheiros nessas novas repartições públicas ${ }^{24}$, estruturando e imprimindo suas diretrizes de trabalho, uma característica que marcou tanto trajetórias profissionais como todo o período republicano.

\section{REFERÊNCIAS}

BEIGUELMAN, P. A formação do povo no complexo cafeeiro: aspectos políticos. São Paulo: Pioneira, 1977.

BERNARDINI, S. P. Os planos da cidade. As políticas de intervenção urbana em Santos - de Estevan Fuertes a Saturnino de Brito (1892-1910). 2003. 328f. Dissertação (Mestrado) Faculdade de Arquitetura e Urbanismo, Universidade de São Paulo, São Paulo, 2003.

BRITO, M. S. A participação da iniciativa privada na produção do espaço urbano: São Paulo, 1890-1911. 2000.213f.Dissertação (Mestrado) - Faculdade de Filosofia,Letras e Ciências Humanas, Universidade de São Paulo, São Paulo, 2000.

BRITO, F. S. R. de. Obras completas de Saturnino de Brito. Engenharia sanitária, v. 4. Rio de Janeiro: Imprensa Nacional, 1943.

BRUNO, E. S. História e tradições da cidade de São Paulo. Burgo de estudantes (1828-1872), v. 2. São Paulo: Hucitec/PMSP, 1984. 
BUENO, L. M. M. O saneamento na urbanização de São Paulo. 1994. 200f. Dissertação (Mestrado) - Faculdade de Arquitetura e Urbanismo, Universidade de São Paulo, São Paulo, 1994.

CAMPOS, C. de. São Paulo pela lente da higiene. As propostas de Geraldo Horácio de Paula Souza para a cidade, 1925-1945. São Carlos: RiMa/Fapesp, 2002.

CANO,W. Raízes da concentração industrial em São Paulo. São Paulo/Rio de Janeiro: Difel, 1977.

CARVALHO, E. C. Projeto de Posturas sobre serviço de esgotos. Arquivos de Higiene e Saúde Pública, São Paulo, v. 3, n. 3, p. 497-499, 1937.

COSTA, L.A. M. Planejando antes do planejamento. Cidade e território em São Paulo, 1886-1903. In: GITAHY,M.L.C.(Org.).Desenhando a cidade do século XX. Estudos de história e fundamentos sociais da arquitetura e do urbanismo em São Paulo, 1870-1970. São Carlos: RiMa/Fapesp, 2005.

O ideário urbano paulista na virada do século. O engenheiro Theodoro Sampaio e as questões territoriais e urbanas modernas (1886-1903). São Carlos: RiMa/Fapesp, 2003.

CSERGO, J. Liberte, égalité, propreté. La morale de l'hygiène au XIXe siécle. Paris: Éditions Albin Michel S.A., 1988.

FONSECA, F. P. Equipamento do Engordador: testemunbo arqueológico industrial da captação de água na cidade de São Paulo. 2003. 79f. Dissertação (Mestrado) - Faculdade de Filosofia, Letras e Ciências Humanas, Universidade de São Paulo, São Paulo, 2003.

GAMA, R. Caracterização do que sejam serviço e obra. São Paulo: FAU/USP, 1974.

LATHAM, B. Sanitary Engineering. London: Spon, 1878.

OSEKI, J. H. Pensar e viver a construção da cidade. Canteiros e desenhos de pavimentação, drenagem de águas pluviais e rede de esgotos em São Paulo. 1992. 226f.Tese (Doutorado) Faculdade de Arquitetura e Urbanismo, Universidade de São Paulo, São Paulo, 1992.

REID, D. Paris sewers and sewermen: realities and representations. Cambridge, Mass/London: Harvard University Press, 1991.

REIS FILHO, N. G. Quadro da arquitetura no Brasil. São Paulo: Perspectiva, 2002.

RODRIGUES, J.A. F.; VALLE, A. Aumento do abastecimento d'águas. Pelos engenheiros civis Fonseca Rodrigues e Ataliba Valle. São Paulo:Tip. Espindola, Siqueira \& C., 1903.

SANTOS, F. M.; LICHTI, F. M. História de Santos/Poliantéia Santista. São Vicente: Editora Caudex, 1996.

SILVA, S. Expansão cafeeira e origens da indústria no Brasil. São Paulo:Alfa-Ômega, 1995.

SINGER, P. Desenvolvimento econômico e evolução urbana. São Paulo: Ed. Nacional, 1974.

VILAR, D. D. Arqueologia industrial e a evolução tecnológica do abastecimento de água na cidade de São Paulo. 2003. 101f. Dissertação (Mestrado) - Faculdade de Filosofia, Letras e Ciências Humanas, Universidade de São Paulo, São Paulo, 2003. 


\section{FONTES MANUSCRITAS}

Arquivo do Estado de São Paulo

COMPANHIA CANTAREIRA \& ESGOTOS. Ofício para o Governo Estadual. São Paulo, 18 de novembro de 1890.

S. Manuscritos/T.I.R./Obras Públicas/Companhia Cantareira e Esgotos/Anos 1883-1890/Caixa 71/Ordem 5.208 .

S. Manuscritos/T.I.R./Obras Públicas/ Companhia Cantareira e Esgotos/Anos 1883-1891/Caixa 72/Ordem 5.209

Biblioteca Municipal Mário de Andrade - São Paulo, Seção de Obras Raras

Coleção de cartas e manuscritos do engenheiro Antonio Francisco de Paula Souza

PS884.01.08 Remetente: PINTO,Adolpho Augusto.

PS890.11.24 Remetente:TIBIRIÇA, Jorge.

Coleção de cartas do conselheiro Antonio Francisco de Paula Souza

PS861.07.01 Remetente: CARRÃO, João da Silva.

\section{FONTES IMPRESSAS}

Leis e Decretos

SÃO PAULO (Estado). Decretos e resoluções do governo provisório do Estado de São Paulo de 18 de novembro de 1889 a 17 de outubro de 1892. São Paulo:Tipografia do Diário Oficial, 1913.

Relatórios do governo

SÃO PAULO (Província). Relatório com que S. Exc.o Sr.Presidente Conselbeiro Joaquim Saldanba Marinho passou a administração da Província de São Paulo a S. Exc. o Sr.Vice-Presidente Coronel Joaquim Floriano de Toledo a 24 de abril de 1868. São Paulo:Tipografia do Ypiranga, 1868.

Relatório apresentado à Assembléia Legislativa Provincial de São Paulo pelo Presidente da Província, o exm. sr. dr. Antonio Candido da Rocha, no dia 2 de fevereiro de 1870. São Paulo:Tipografia Americana, 1870a. 
Ofício pelo qual o Exmo. sr. vice-presidente da Província, Conselheiro Vicente Pires da Motta, passou a administração da mesma ao exm. sr. dr.Antonio da Costa Pinto Silva. São Paulo, 5 de novembro de 1870 b.

Relatório apresentado à Assembléia Legislativa Provincial de São Paulo pelo presidente da Província, o exmo. Sr. Dr.Antonio da Costa Pinto Silva, no dia 5 de fevereiro de 1871. São Paulo:Tipografia Americana, 1871.

Relatório apresentado à Assembléia Legislativa Provincial de São Paulo pelo presidente da Província, o exmo. Sr. Dr.José Fernandes da Costa Pereira Junior, em 2 de fevereiro de 1872. São Paulo:Tipografia Americana, 1872.

Relatório apresentado à Assembléia Legislativa Provincial pelo exmo. Sr. Dr.João Theodoro Xavier, no dia 5 de fevereiro de 1873. São Paulo:Tipografia Americana, 1873.

Relatório apresentado à Assembléia Legislativa Provincial de São Paulo pelo presidente da Província, o exmo. Sr. Dr. João Theodoro Xavier em 5 de fevereiro de 1874. São Paulo: Tipografia Americana, 1874

Relatório apresentado à Assembléia Legislativa Provincial de São Paulo pelo exmo. Sr. Dr.João Theodoro Xavier, presidente da Província, no dia 14 de fevereiro de 1875. São Paulo:Tipografia do Diário, 1875.

Relatório apresentado à Assembléia Legislativa Provincial de São Paulo pelo presidente da Província, exmo.Sr.Dr.Sebastião José Pereira, em 2 de fevereiro de 1876. São Paulo:Tipografia do Diário, 1876.

Relatório apresentado à Assembléia Legislativa Provincial de São Paulo pelo presidente da Província, Laurindo Abelardo de Brito, no dia 5 de fevereiro de 1880. Santos:Tipografia a vapor do Diário de Santos, 1880.

Relatório apresentado à Assembléia Legislativa Provincial de São Paulo pelo presidente da Província, Laurindo Abelardo de Brito, no dia 13 de janeiro de 1881. Santos:Tipografia a Vapor do Diário de Santos, 1881.

Relatório dirigido à Assembléia Legislativa Provincial de São Paulo pelo $1^{\circ}$ vicepresidente da Província, Conde de Três Rios, e apresentado no ato da instalação da mesma Assembléia pelo $4^{\circ}$ vice-presidente, dr. Manoel Marcondes de Moura e Costa. Santos:Tipografia a Vapor do Diário de Santos, 1882.

Fala dirigida à Assembléia Legislativa Provincial de São Paulo na abertura da $2^{a}$ sessão da $24^{a}$ legislatura em 10 de janeiro de 1883 pelo presidente Conselheiro Francisco de Carvalho Soares Brandão. São Paulo:Tipografia do Ipiranga, 1883a.

Relatório com que passou a administração da Província de São Paulo ao exmo. Presidente Barão de Guajará, o vice-presidente Visconde de Itu. São Paulo: Tipografia do Comercio, $1883 \mathrm{~b}$.

Fala dirigida à Assembléia Legislativa Provincial de São Paulo na abertura da $1^{a}$ 
sessão da $25^{a}$ legislatura em 16 de janeiro de 1884 pelo presidente, Barão de Guajará. São Paulo:Tipografia da Gazeta Liberal, 1884.

. Fala dirigida à Assembléia Legislativa Provincial de São Paulo na abertura da $2^{a}$ sessão da $26^{a}$ legislatura em 10 de janeiro de 1885 pelo presidente, dr.José Luiz de Almeida Couto. São Paulo:Tipografia da Gazeta Liberal, 1885.

Relatório com que o exmo. Sr. Dr.José Luiz de Almeida Couto passou a administração ao $1^{\circ}$ vice-presidente, exmo. Sr. Dr. Francisco Antonio de Souza Queiroz Filbo. São Paulo: Tipografia do Correio Paulistano, 1886.

Relatório apresentado á Assembléia Legislativa Provincial de São Paulo pelo presidente da Província Barão de Parnaíba, no dia 17 de janeiro de 1887. São Paulo:Tipografia a vapor de Jorge Seckler \& Comp., 1887.

Exposição com que o exm. Sr.Visconde do Parnaíba passou a administração da Província de São Paulo ao exm. Sr. Dr. Francisco de Paula Rodrigues Alves presidente dessa Província no dia 19 de novembro de 1887. São Paulo:Tipografia a Vapor de Jorge Seckler \& Comp., 1888.

Relatório apresentado à Assembléia Legislativa Provincial de São Paulo pelo Presidente da Província Dr. Pedro Vicente de Azevedo no dia 11 de janeiro de 1889. São Paulo:Tipografia a vapor de Jorge Seckler \& Comp., 1889a.

Fala com que o Exm. Sr. Dr. Barão de Jaguará abriu a sessão extraordinária da Assembléia Legislativa Provincial de São Paulo no dia 20 de maio de 1889. São Paulo:Tipografia a vapor de Jorge Seckler \& Comp., 1889b.

Exposição apresentada ao Dr.Jorge Tibiriçá pelo Dr. Prudente J. de Moraes Barros, $1^{\circ}$ Governador do Estado de São Paulo ao passar-lhe a administração no dia 18 de outubro de 1890. São Paulo:Tipografia Vanorden \& Comp., 1890.

Fala dirigida ao Congresso Constituinte de São Paulo pelo Governador do Estado, Dr.Américo Brasiliense de Almeida Mello, no dia 8 de junbo de 1891.

Mensagem dirigida ao congresso Legislativo de São Paulo, pelo vice-presidente do Estado, Dr.José Alves de Cerqueira César, no dia 7 de Abril de 1892. In:Mensagens apresentadas ao Congresso Legislativo de São Paulo pelos presidentes e vice-presidentes em exercício, desde a proclamação da República até o ano de 1916. São Paulo:Tipografia do Diário Oficial, 1916a.

Mensagem de 07 de abril de 1892. Mensagem dirigida ao Congresso Legislativo de São Paulo, pelo Vice-Presidente do Estado, Dr. José Alves de Cerqueira César, no dia 7 de Abril de 1892. In: Mensagens apresentadas ao Congresso Legislativo de São Paulo pelos presidentes e vicepresidentes em exercício, desde a proclamação da República até o ano de 1916. São Paulo: Tipografia do Diário Oficial, 1916b.

. Mensagem de 7 de Abril de 1893. Mensagem dirigida ao Congresso de São Paulo, pelo Dr. Bernardino de Campos, Presidente do Estado. In: Mensagens apresentadas ao Congresso 
Legislativo de São Paulo pelos presidentes e vice-presidentes em exercício, desde a proclamação da República até o ano de 1916. São Paulo:Tipografia do Diário Oficial, 1916c.

Mensagem de 7 de abril de 1894. Mensagem dirigida ao Congresso Legislativo de São Paulo, pelo Presidente do Estado, Dr. Bernardino de Campos. In: Mensagens apresentadas ao Congresso Legislativo de São Paulo pelos presidentes e vice-presidentes em exercício, desde a proclamação da República até o ano de 1916. São Paulo:Tipografia do Diário Oficial, 1916d.

Mensagem de 7 de abril de 1895. Mensagem dirigida ao Congresso Legislativo de São Paulo, pelo Presidente do Estado, Dr. Bernardino de Campos. In: Mensagens apresentadas ao Congresso Legislativo de São Paulo pelos presidentes e vice-presidentes em exercício, desde a proclamação da República até o ano de 1916. São Paulo:Tipografia do Diário Oficial, 1916e.

.Mensagem de 7 de abril de 1896. Mensagem dirigida ao Congresso Legislativo de São Paulo, pelo Presidente do Estado, Dr. Bernardino de Campos. In:Mensagens apresentadas ao Congresso Legislativo de São Paulo pelos presidentes e vice-presidentes em exercício, desde a proclamação da República até o ano de 1916. São Paulo:Tipografia do Diário Oficial, 1916f.

Relatórios de órgãos do governo

COMISSÃO DE SANEAMENTO DO ESTADO de São Paulo. In: SÃO PAULO (Estado). Relatório apresentado ao Dr. Presidente do Estado de São Paulo pelo Dr.Jorge Tibiriçá, Secretário dos Negócios da Agricultura, Comércio e Obras Públicas em 4 de abril de 1893. Rio de Janeiro: Tip. G. Leuzinger \& Filhos, 1893.

REBOUÇAS, J. P. Relatório apresentado pela Superintendência de Obras Públicas do Estado de São Paulo, em 31 de março de 1892 ao cidadão Dr.Alfredo Maia, digno Secretário dos Negócios da Agricultura, Comercio e Obras Públicas deste Estado. São Paulo, 1892.

RELATÓRIO ANUAL DA SECRETARIA DOS NEGÓCIOS da Agricultura, Comércio e Obras Públicas apresentado ao Dr. Jorge Tibiriçá em 15 de fevereiro de 1895. In: SÃO PAULO (Estado). Relatório da Secretaria dos Negócios da Agricultura, Comércio e Obras Públicas do Estado de São Paulo, apresentado em 3 de março de 1895 ao Dr. Bernardino de Campos, Presidente do Estado pelo Dr.Jorge Tibiriçá, Secretário de Estados. São Paulo:Tipografia Paulista, 1895.

RELATÓRIO APRESENTADO PELA SUPERINTENDÊNCIA de Obras Públicas do Estado de São Paulo em 26 de fevereiro de 1894 ao cidadão Dr. Jorge Tibiriçá, muito digno Secretário dos Negócios da Agricultura, Comercio e Obras Públicas. In: SÃO PAULO (Estado). Relatório da Secretaria dos Negócios da Agricultura, Comércio e Obras Públicas do Estado de São Paulo, apresentado em 3 de março de 1895 ao Dr.Bernardino de Campos, Presidente do Estado pelo Dr.Jorge Tibiriçá, Secretário de Estados. São Paulo:Tipografia Paulista, 1895.

SÃO PAULO (Estado). Relatório apresentado ao Dr.Vice-Presidente do Estado de São Paulo pelo Dr. Alfredo Maia - Secretário de Estado dos Negócios da Agricultura, Comércio e Obras Públicas. São Paulo:Tip. de Vanorden, 1892.

Relatório apresentado ao Dr. Presidente do Estado de São Paulo pelo Dr.Jorge Tibiriçá, 
Secretário dos Negócios da Agricultura, Comércio e Obras Públicas em 4 de abril de 1893. Rio de Janeiro:Tip. G. Leuzinger \& Filhos, 1893a.

Relatório apresentado pela Superintendência de Obras Públicas do Estado de São Paulo em 27 de fevereiro de 1893 ao cidadão Dr. Jorge Tibiriçá, Digno Secretário dos Negócios da Agricultura, Comércio e Obras Públicas deste Estado. In: SÃO PAULO (Estado). Relatório apresentado ao Dr. Presidente do Estado de São Paulo pelo Dr.Jorge Tibiriçá, Secretário dos Negócios da Agricultura, Comércio e Obras Públicas em 4 de abril de 1893. Rio de Janeiro: Tip. G. Leuzinger \& Filhos, 1893b.

SOUZA,A. F. de P. Relatório da Diretoria da Superintendência das Obras Públicas. In: SÃO PAULO (Estado). Exposição apresentada ao Dr.Jorge Tibiriçá pelo Dr. Prudente J. de Moraes Barros $1^{\circ}$ Governador do Estado de São Paulo ao passar-lhe a administração no dia 18 de outubro de 1890. São Paulo:Tip.Vanorden \& Comp., 1890.

SUPERINTENDENCIA DE OBRAS Públicas do Estado de São Paulo. Ofício ao cidadão Dr. Governador do Estado. São Paulo, 14 de outubro de 1890.

Relatórios dos engenheiros fiscais

REDONDO, M. F. G. Relatório do engenheiro fiscal da Companbia Cantareira E Esgotos, em 18 de dezembro de 1889. São Paulo, 1889.

Esclarecimentos e informações fornecidas ao Exm. Presidente da Província General Couto de Magalhães pelo engenheiro fiscal M. F. Garcia Redondo. São Paulo:Tip. a vapor de Jorge Seckler \& Comp., 1889.

SÍTIOS NA INTERNET

Informações sobre James Brunless: www.novomilenio.inf.br/santos/h0102.htm

Gazetteer for Scotland: www.geo.ed.ac.uk

Relatórios do Governo: www.crl.edu/content/brazilianSeriesDocs.htm

Artigo apresentado em 06/2005. Aprovado em 10/2005. 